\title{
Springtime daily variations in lower-tropospheric ozone over east Asia: the role of cyclonic activity and pollution as observed from space with IASI
}

\author{
G. Dufour ${ }^{1}$, M. Eremenko ${ }^{1}$, J. Cuesta ${ }^{1}$, C. Doche ${ }^{2}$, G. Foret ${ }^{1}$, M. Beekmann ${ }^{1}$, A. Cheiney ${ }^{3,1}$, Y. Wang ${ }^{4}$, Z. Cai ${ }^{4}$, \\ Y. Liu ${ }^{4}$, M. Takigawa ${ }^{5}$, Y. Kanaya ${ }^{5}$, and J.-M. Flaud ${ }^{1}$ \\ ${ }^{1}$ Laboratoire Inter-universitaire des Systèmes Atmosphériques (LISA), UMR7583, Universités Paris-Est Créteil et Paris \\ Diderot, CNRS, Créteil, France \\ ${ }^{2}$ Météo France, Direction Inter-Régionale Sud-Ouest, Division Etudes et Climatologie, Mérignac, France \\ ${ }^{3}$ Institut National de l'Environnement industriel et des RISques, INERIS, Verneuil-en-Halatte, France \\ ${ }^{4}$ Key Laboratory of Middle Atmosphere and Global Environment Observation, Institute of Atmospheric Physics, Chinese \\ Academy of Sciences, Beijing, China \\ ${ }^{5}$ Japan Agency for Marine-Earth Science and Technology, Yokohama, Japan
}

Correspondence to: G. Dufour (gaelle.dufour@ lisa.u-pec.fr)

Received: 18 February 2015 - Published in Atmos. Chem. Phys. Discuss.: 27 March 2015

Revised: 28 August 2015 - Accepted: 13 September 2015 - Published: 29 September 2015

\begin{abstract}
We use satellite observations from IASI (Infrared Atmospheric Sounding Interferometer) on board the MetOpA satellite to evaluate the springtime daily variations in lower-tropospheric ozone over east Asia. The availability of semi-independent columns of ozone from the surface up to $12 \mathrm{~km}$ simultaneously with CO columns provides a powerful observational data set to diagnose the processes controlling tropospheric ozone enhancement on synoptic scales. By combining IASI observations with meteorological reanalyses from ERA-Interim, we develop an analysis method based only on IASI ozone and CO observations to identify the respective roles of the stratospheric source and the photochemical source in ozone distribution and variations over east Asia. The succession of low- and high-pressure systems drives the day-to-day variations in lower-tropospheric ozone. A case study analysis of one frontal system and one cut-off low system in May 2008 shows that reversible subsiding and ascending ozone transfers in the upper-troposphere-lowerstratosphere (UTLS) region, due to the tropopause perturbations occurring in the vicinity of low-pressure systems, impact free and lower-tropospheric ozone over large regions, especially north of $40^{\circ} \mathrm{N}$, and largely explain the ozone enhancement observed with IASI for these latitudes. Irreversible stratosphere-troposphere exchanges of ozone-rich
\end{abstract}

air masses occur more locally in the southern and southeastern flanks of the trough. The contribution to the lowertropospheric ozone column is difficult to dissociate from the tropopause perturbations generated by weather systems. For regions south of $40^{\circ} \mathrm{N}$, a significant correlation has been found between lower-tropospheric ozone and carbon monoxide (CO) observations from IASI, especially over the North China Plain (NCP). Considering carbon monoxide observations as a pollutant tracer, the $\mathrm{O}_{3}-\mathrm{CO}$ correlation indicates that the photochemical production of ozone from primary pollutants emitted over such large polluted regions significantly contributes to the ozone enhancements observed in the lower troposphere via IASI. When low-pressure systems circulate over the NCP, stratospheric and pollution sources play a concomitant role in the ozone enhancement. IASI's 3-D observational capability allows the areas in which each source dominates to be determined. Moreover, the studied cut-off low system has enough potential convective capacity to uplift pollutants (ozone and $\mathrm{CO}$ ) and to transport them to Japan. The increase in the enhancement ratio of ozone to $\mathrm{CO}$ from 0.16 on 12 May over the North China Plain to 0.28 over the Sea of Japan on 14 May indicates photochemical processing during the plume transport. 


\section{Introduction}

In addition to being an important greenhouse gas (Stevenson et al., 2013), tropospheric ozone $\left(\mathrm{O}_{3}\right)$ plays a central role in atmospheric chemistry and air quality by controlling the oxidation processes through the formation of hydroxyl radicals $(\mathrm{OH})$ (Monks, 2005; Monks et al., 2015). Ozone at high concentrations near the surface is a pernicious pollutant, harmful both to human health and to vegetation (Seinfeld and Pandis, 1997; WHO, 2013). Enhancements of ozone in the mid- and lower troposphere result from photochemical production from precursors $\left(\mathrm{NO}_{x}\right.$ and hydrocarbons) and from stratosphere-troposphere exchanges (STEs) (Lelieveld and Dentener, 2000). The relative contributions made by these sources depend on the season. It is well established that the peak activity of STE occurs during winter and spring (Monks, 2000), whereas photochemical production is more active during the summer period. The crucial role played by weather systems (cyclonic activity) in determining tropospheric ozone variation has also been well established (e.g. Carmichael et al., 1998; Cooper et al., 1998, 2002a; Ding et al., 2009). These weather systems are associated with tropopause perturbation, especially low tropopauses, and then with subsiding and ascending ozone transfer in the upper-troposphere-lower-stratosphere (UTLS) region. In addition, irreversible transfers of ozone can be expected, such as stratosphere-troposphere exchanges that would take place preferentially on the western and southern flanks of the trough (e.g. Ancellet et al., 1994; Holton et al., 1995; Liu et al., 2013), and downward transport from the UTLS to the lower troposphere (e.g. Cooper et al., 2002a). Conceptual models have been proposed to describe airstreams related to travelling low-pressure systems at the midlatitudes (e.g. Cooper et al., 2002b). Two main mechanisms are responsible for part of the ozone temporal and spatial variations observed in the troposphere. The dry airstream (DA) occurring behind cold fronts is responsible for a strong downward transport of ozone from the UTLS down to the middle troposphere. It is often linked to tropopause folding. This downward transport can affect ozone concentrations down to the surface, especially at high-altitude sites (e.g. Carmichael et al., 1998; Schuepbach et al., 1999; Dempsey, 2014). In contrast, air masses and then pollutants can be uplifted from the surface to the free troposphere by different processes such as deep convection, orographic lifting and frontal lifting (e.g. Bethan et al., 1998; Hannan et al., 2003; Miyazaki et al., 2003; Cooper et al., 2004, Ding et al., 2009, 2015; Foret et al., 2014, and references therein). One part of these processes, the warm conveyor belts (WCBs) associated with frontal activity and lifting have been studied mainly in the context of their role in the long-range transport of pollutants because they lift pollutants to levels where horizontal transport is more efficient. Several studies focusing on the trans-Pacific transport of pollutants from east Asia towards the United States have shown the importance of the frontal systems in this transport process during springtime using both model simulations (e.g. Bey et al., 2001; Liu et al., 2003; Mari et al., 2004; Lin et al., 2010) and dedicated field campaigns (e.g. Jaffe et al., 1999; Cooper et al., 2004; Liang et al., 2004; Oshima et al., 2004). Very recently, Ding et al. (2015) have shown that the topography of east Asia, as well as inducing orographic lifting, assists frontal lifting and facilitates convection, thereby amplifying the possibility of pollutant uplifting.

In recent decades, east Asia, and in particular China, has experienced rapid economic growth. The related increasing anthropogenic emissions of pollutants (Richter et al., 2005; Lin et al., 2013) lead to regional ozone concentrations that are amongst the highest in the world (e.g. Chan and Yao, 2008; Zhao et al., 2009; Lelieveld and Dentener, 2000; Wang et al., 2012; Safieddine et al., 2013). Due to the rapidly changing emissions in China, the respective contribution made by anthropogenic and natural perturbations to tropospheric ozone in China and its variability constitutes a crucial issue to be documented and better understood. Seasonal variations in ozone levels in east Asia and especially the role of the summer Asian monsoon leading to a summer minimum have been extensively studied from model simulations and in situ and satellite observations (e.g. Mauzerall et al., 2000; Tanimoto et al., 2005; Yamaji et al., 2006; Li et al., 2007; Ding et al., 2008; Dufour et al., 2010). However, on the synoptic scale, the direct impact of weather systems on tropospheric ozone distribution above China and its daily variations has been less extensively considered or, if so, mainly in the context of the long-range transport of pollutants and export to the Pacific Ocean. A recent study investigates the dynamic and chemical features induced in the upper troposphere by cut-off lows over northeast China using limb and nadir satellite sounders (Liu et al., 2013).

The progress made in satellite observations of tropospheric ozone during the last decade (e.g. Worden et al., 2007; Eremenko et al., 2008; Liu et al., 2010, Nakatani et al., 2012) offers a new opportunity to evaluate ozone distribution and its daily variation including the role of transport on the synoptic scale (e.g. Doche et al., 2014). The satellite provides an unprecedented spatial coverage that allows new insight into how synoptic processes impact ozone distributions. The first satellite measurements of tropospheric ozone were obtained using ultraviolet-visible (UV-vis) sounders (e.g. Fishman et al., 2003; Liu et al., 2007). Later on, the development of thermal infrared nadir sounders allowed accurate measurements of partial tropospheric ozone columns to be obtained (Coheur et al., 2005; Worden et al., 2007; Dufour et al., 2012; Safieddine et al., 2013). Using Global Ozone Monitoring Experiment (GOME) and Ozone Monitoring Instrument (OMI), Nakatani et al. (2012) show a persistent belt of enhanced tropospheric columns of ozone at midlatitudes over east Asia throughout the year, partly attributed to stratospheric intrusion near the subtropical jet. The tropospheric contribution to the enhanced ozone column has been assessed using model simulations. Nakatani et al. (2012) underlined the difficulty 
in differentiating the stratospheric and tropospheric origins of ozone in the tropospheric columns observed by satellite. This difficulty has already been stated by de Laat et al. (2005). However, it has been demonstrated that thermal infrared sounders like IASI (Infrared Atmospheric Sounding Interferometer) on board MetOp (Clerbaux et al., 2009) allow the retrieval of semi-independent partial columns of ozone within the troposphere (Eremenko et al., 2008; Dufour et al., 2010, 2012; Safieddine et al., 2013; Barret et al., 2011). Dufour et al. (2010) show the ability of IASI to provide independent information on the seasonal variation in lowerand upper-tropospheric ozone over east Asia. Over shorterterm periods of the order of several days, the retrieved ozone profile with IASI allows the identification of the origin of the observed tropospheric ozone in specific cases. Very recently, Hayashida et al. (2015) show ozone enhancement in the lower troposphere over east Asia using the OMI spaceborne ultraviolet spectrometer. They attribute the enhancement mainly to emissions of ozone precursors from open crop residue burning after the winter wheat harvest.

In this paper, we use the IASI observation of lowertropospheric ozone to investigate the influence of synopticscale weather systems on the distribution of ozone over east Asia. In a previous study, Dufour et al. (2010) show that IASI lower-tropospheric ozone columns reach a maximum in late spring and early summer (May, June) in Beijing, Shanghai and Hong Kong. We then decided to focus our study on late spring (May), a period during which high ozone concentrations and frequent frontal activities occur over east Asia. We focus on May 2008, as this was the first period available with the new version of the IASI ozone product used for this study. Two case studies, which are associated with travelling low-pressure systems and which present enhanced ozone in the lower troposphere, are analysed. The first case is used to develop the analysis method based on IASI observations of ozone $\left(\mathrm{O}_{3}\right)$ and carbon monoxide $(\mathrm{CO})$. We demonstrate that semi-independent ozone columns between the surface and $12 \mathrm{~km}$ from IASI associated with simultaneous CO measurements provide a powerful observational data set to identify, at least partly, the stratospheric and anthropogenic origin of lower free-tropospheric ozone. The contributions made to the enhanced lower-tropospheric ozone columns by descending air from the UTLS in the vicinity of the weather systems and by the photochemical production of ozone are then investigated for the two case studies.

The paper is structured as follows. In Sect. 2, the different satellite and meteorological data sets are described. As a new version of the IASI ozone product is used for this study, we provide a summary of the validation of the product with a specific focus on east Asia in Sect. 3. The analysis method based on ozone and CO columns is detailed in Sect. 4. Section 5 presents the consequences of a cut-off low travelling over a highly polluted region (North China Plain) in terms of ozone vertical distribution and pollutant transport. A general discussion is given in Sect. 6 and a conclusion in Sect. 7.

\section{Data set description}

\subsection{The IASI instrument}

The IASI (Infrared Atmospheric Sounding Interferometer) (Clerbaux et al., 2009) instrument, on board the MetOpA platform since October 2006, is a nadir-viewing Fourier transform spectrometer. It operates in the thermal infrared between 645 and $2760 \mathrm{~cm}^{-1}$ with an apodized resolution of $0.5 \mathrm{~cm}^{-1}$. The field of view of the instrument is composed of a $2 \times 2$ matrix of pixels with a diameter at nadir of $12 \mathrm{~km}$ each. IASI scans the atmosphere with a swath width of $2200 \mathrm{~km}$ and crosses the equator at two fixed local solar times (09:30, descending mode, and 21:30, ascending mode), allowing the monitoring of atmospheric composition twice a day at any location. The large spectral coverage, high radiometric sensitivity and accuracy, and rather high spectral resolution of the instrument allow it to measure the global distribution of several important atmospheric species (e.g. Boynard et al., 2009; George et al., 2009; Clarisse et al., 2011).

\subsection{Lower-tropospheric ozone from IASI}

The IASI ozone profiles and partial columns considered in this paper have been retrieved using the method described in Eremenko et al. (2008). The retrieval is performed using the radiative transfer model KOPRA (Karlsruhe Optimised and Precise Radiative transfer Algorithm) and its inversion module KOPRAFIT (Stiller et al., 2000; Höpfner et al., 2001), both adapted to the nadir-viewing geometry. A constrained least squares fit method with an analytical altitudedependent regularization is used (Kulawik et al., 2006). The applied regularization method is detailed in Eremenko et al. (2008). To summarize, the regularization matrix is a combination of first-order Tikhonov constraints (Tikhonov, 1963) with altitude-dependent coefficients. The coefficients are optimized both to maximize the degrees of freedom (DOFs) of the retrieval and to minimize the total error on the retrieved profile. Compared to previous studies using this algorithm (Eremenko et al., 2008; Dufour et al., 2010, 2012), several changes have been made. The emissivity of the surface is now taken into account based on a global monthly IASI-derived climatology (Zhou et al., 2011) allowing a better retrieval above arid regions. Different a priori and constraints are used depending on the tropopause height. This new scheme was introduced to reduce possible compensation effects during the retrieval procedure. An automatic detection of the tropopause height (calculated from the temperature profile retrieved from IASI using the definition based on the lapse rate criterion; WMO, 1957) has been introduced to discriminate between polar, midlatitudes, and tropical situations. If the tropopause is lower than $10 \mathrm{~km}$, the polar constraint and a priori profile are used. If the tropopause is between 10 and $14 \mathrm{~km}$, the midlatitude constraint and a priori profile are used. If the tropopause is higher than $14 \mathrm{~km}$, the 
tropical constraint and a priori are used. The midlatitude and tropical regularization matrices are those already used in Eremenko et al. (2008) and Dufour et al. $(2010,2012)$ respectively. The polar constraint has been specifically developed following the same method as in Eremenko et al. (2008). The a priori profiles are compiled from the ozonesonde climatology of McPeters et al. (2007). The midlatitude a priori profile is set to the climatological profile of the $30-60^{\circ} \mathrm{N}$ latitude band for summer. The tropical a priori profile is set to the climatological profile of the $10-30^{\circ} \mathrm{N}$ latitude band over the year. The polar profile is set to the climatological profile of the $60-90^{\circ} \mathrm{N}$ latitude band for summer. As the version of the ozone product used in this study differs significantly from the version extensively validated in Dufour et al. (2012), a new validation against ozonesondes has been conducted and the results are presented in Sect. 3. The modifications of the algorithm do not influence the vertical sensitivity of IASI. As shown in Dufour et al. $(2010,2012)$, two semi-independent partial columns of ozone between the surface and $12 \mathrm{~km}$ can be considered: the lower-tropospheric column integrating the ozone profile from the surface to $6 \mathrm{~km}$ altitude - above sea level (a.s.l.) - and the upper-tropospheric column integrating the ozone profile from 6 to $12 \mathrm{~km}$ altitude. Note that the latter column can include stratospheric air masses depending on the tropopause height. The averaging kernels give information on the vertical sensitivity and resolution of the retrieval. The lower-tropospheric column shows a maximum sensitivity typically between 3 and $4 \mathrm{~km}$ with a limited sensitivity to the surface (Dufour et al., 2012). This implies that the ozone concentration profile in the lower troposphere is preferentially incremented at these altitudes during the retrieval process, independent of whether the true ozone profile is perturbed at other altitudes, especially at the surface. Moreover, it is worth noting that the partial columns are only semi-independent which means that they may include partial information from altitudes outside their altitude range. For example, the lower-tropospheric column includes information from altitudes higher than its upper limit $(6 \mathrm{~km})$. In order to estimate the fraction of contamination of the lowertropospheric column by higher altitudes, we calculated the ratio between the integral of the averaging kernel of the lower-tropospheric column from 6 to $60 \mathrm{~km}$ and the integral from the surface to $60 \mathrm{~km}$. Higher atmospheric layers contribute to about 20 to $30 \%$ of the lower-tropospheric column in the midlatitude air masses (not shown). Note that only the morning overpasses of IASI are considered for this study in order to remain in thermal conditions with a better sensitivity to the lower troposphere.

\subsection{Carbon monoxide from IASI}

The CO data used here are retrieved from the IASI spectra within the $2143-2181.25 \mathrm{~cm}^{-1}$ spectral range using the FORLI-CO (Fast Optimal Retrievals on Layers for IASI for $\mathrm{CO})$ retrieval code from the Université Libre de Bruxelles
(ULB). FORLI-CO retrievals give CO concentration profiles using the optimal estimation method (Rodgers, 2000) and a single a priori profile. More details are given in Hurtmans et al. (2012). The IASI FORLI-CO product used in this study is the total column, publicly available from the Ether website (http://www.pole-ether.fr). Note that only half of the pixels are available for the year 2008. This explains the difference in measurement density between $\mathrm{O}_{3}$ and $\mathrm{CO}$ observations in the different figures. Carbon monoxide is often used as an indicator of biomass burning and anthropogenic pollution (e.g. Edwards et al., 2004; McMillan et al., 2010). In this study, we use the IASI CO columns as an anthropogenic pollution tracer.

\subsection{Meteorological data set}

Meteorological data from the ECMWF ERA-Interim reanalysis are used in our analyses. The reanalysis is based on a 4-D-Var assimilation system with a $12 \mathrm{~h}$ analysis window. The spatial resolution of the data set is approximately $80 \mathrm{~km}$ on 60 vertical levels from the surface up to $0.1 \mathrm{hPa}$ (Dee et al., 2011). In our analyses, the meteorological parameters are taken at 00:00 UTC, corresponding roughly to the morning overpass time of IASI. The main variables considered in this study are the geopotential height, the potential vorticity (PV), and the horizontal wind field ( $u$ and $v$ components), as well as the equivalent potential temperature, the vertical velocity and the convective available potential energy. The geopotential height associated with horizontal wind at $850 \mathrm{hPa}$ gives a proxy for describing the weather situation and horizontal transport in the lower troposphere, whereas the same parameters at $300 \mathrm{hPa}$ describe the situation in the UTLS. We also calculate the equivalent potential temperature at 850 and $300 \mathrm{hPa}$ from temperature, relative humidity and specific humidity fields (Bolton, 1980) as an indicator of air mass origin (Holton, 2004). Potential vorticity (PV) is often used as a tracer of tropopause height and of air mass origin (e.g. Bethan et al., 1996). PV values between 1 and 1.6 PVU are representative of the upper troposphere, whereas PV values larger than 1.6 PVU are indicators of air mass origin above the dynamical tropopause. In this study, we consider mainly $\mathrm{PV}$ averaged at between 300 and $500 \mathrm{hPa}$ with a $50 \mathrm{hPa}$ interval as we are above all interested in the impact of stratospheric air masses on the free troposphere. In order to investigate the ascending motion of air masses, especially from the boundary layer towards the free troposphere within weather systems, we examine the vertical velocity at different pressure levels as well as the convective available potential energy (CAPE), which provides information on the capability of the low-pressure system to vertically transport air masses by convection. 


\section{Validation of IASI lower-tropospheric ozone}

Significant changes in the ozone retrieval procedure compared to the validation exercise reported in Dufour et al. (2012) have been made as described in Sect. 2.2. A new validation exercise was done to evaluate the new version of the ozone product. We use a database of ozonesonde measurements from 2007 to 2012 including 27 stations in the midlatitudinal band $\left(30-60^{\circ}\right)$ in both hemispheres and 16 stations in the tropical band $\left(30^{\circ} \mathrm{S}\right.$ to $\left.30^{\circ} \mathrm{N}\right)$. Most of the ozonesonde measurements are from the WOUDC (World Ozone and Ultraviolet Radiation Data Centre, http://woudc. org/) and SHADOZ (Southern Hemisphere ADditional OZonesondes, http://croc.gsfc.nasa.gov/shadoz/) databases, except for those at Aquila and Beijing. A list of stations and related information is provided in Table 1 . The coincidence criteria used for the validation are $1^{\circ}$ around the station, a time difference smaller than $6 \mathrm{~h}$ and a minimum of 10 clear-sky pixels matching these criteria. The results of the comparison between IASI ozone retrievals and ozonesonde measurements are summarized in Table 2 . We focus on the lower troposphere, and no correction factor has been applied on ozonesonde measurements. The results for other partial columns are not significantly different compared to the previous version of the product, extensively discussed by Dufour et al. (2012). The bias for the lower-tropospheric column (surface to $6 \mathrm{~km}$ a.s.l.) is small $(-0.6 \mathrm{DU},-2.8 \%)$ and comparable to the bias estimated at the midlatitudes with the previous version of the product (Dufour et al., 2012). The estimated error is about $2.8 \mathrm{DU}(14 \%)$, with a correlation coefficient of 0.70 . Table 2 also summarizes the results for east Asian ozonesonde stations only (Beijing, Hong Kong, Sapporo and Tateno). A significant bias of $2.2 \mathrm{DU}$ $(9.5 \%)$ with IASI underestimating ozone partial columns is determined. The bias is similar for Beijing, Hong Kong, and Tateno ( $-2.6 \mathrm{DU})$ and different for Sapporo (+0.8 DU). Most of the ozonesonde measurements are performed in the early afternoon. The ozone build-up is then maximal in polluted urban or suburban sites like Beijing, Hong Kong, and Tateno. IASI observations are performed in the morning, about $5 \mathrm{~h}$ earlier on average. The time difference between IASI and ozonesonde observations in polluted suburban sites may partly explain the larger bias in this case. Indeed, the bias for the Sapporo region, where the diurnal cycle of ozone is limited, is reduced. However, the small number of coincidences does not allow any firm conclusion to be reached on the origin of the observed bias over east Asia.

\section{Case study of 4-6 May 2008: the use of IASI $\mathrm{O}_{3}$ and $\mathrm{CO}$ to diagnose the processes influencing the ozone distribution affected by weather systems}

An episode of high ozone is observed in the lower troposphere with IASI in northeast Asia from 4 to 6 May 2008.
This episode is associated with a low-pressure system travelling from Mongolia through north China to the extreme north of Japan. In this section, we investigate how to use the ozone partial columns and profiles and the CO total columns from IASI to diagnose which processes contribute to the ozone enhancement.

\subsection{Low-pressure system and associated IASI ozone distribution}

Figure 1 describes the meteorological situation of this episode of high ozone. A large cold front extending from Mongolia to southern China on 4 May 2008, from north China to the southern Japanese islands on 5 May 2008, and moving eastward from Japan on 6 May 2008 characterizes the low-pressure system (Fig. 1a-c). The regions behind the frontal area and north of the polar jet, situated between 35 and $40^{\circ} \mathrm{N}$ on these dates (Fig. 1d-f), are strongly influenced by polar air masses with tropopause heights below $9 \mathrm{~km}$ (Fig. 1g-i). The 300-500 hPa mean PV values are larger than 1.6 PVU for the same regions, indicating that the upper troposphere is under the influence of lower-stratospheric air masses (Fig. 2j-1). The spatial correlation of low tropopauses and large PV values indicates that reversible subsiding ozone transfer affects the upper troposphere in this case. We then expect an ozone enhancement in the upper troposphere for these regions, and we will see in the following how IASI describes this ozone enhancement induced by ozone subsidence. The analysis of the upper-tropospheric columns shows that IASI observes columns larger than $40 \mathrm{DU}$ in the regions affected by low tropopauses and large PV (Fig. $2 \mathrm{~g}$ i). A step gradient between 30 and $40 \mathrm{DU}$ is observed in the upper-tropospheric ozone distribution reflecting the step gradient in the PV distribution. The very good spatial correlation of the high-UT ozone structures with those of high PV leads us to consider that the upper-tropospheric columns of ozone retrieved from IASI can be used as a proxy to determine the regions affected by subsiding ozone from the lower stratosphere. The threshold of $40 \mathrm{DU}$ seems to be relevant to this identification.

The question now is to determine to what extent IASI is able to provide information about the low-pressure system's influence on the lower-tropospheric ozone distribution. The physical processes, which may affect the lowertropospheric ozone distribution, are (i) the reversible ozone subsidence associated with low-tropopause heights, which induces an enhancement of ozone in the upper and free troposphere and then partly in the lower troposphere; (ii) irreversible stratosphere-troposphere exchanges, which also lead to ozone enhancement. The first process is expected to affect ozone distribution on a synoptic scale, whereas the second process is more localized. Figure $2 \mathrm{a}-\mathrm{c}$ show that lowertropospheric ozone columns larger than $28 \mathrm{DU}$ are observed with IASI in the vicinity of the low with similar spatial patterns to the UT columns and the PV distribution. The ob- 
Table 1. Ozonesonde stations used for the validation. " $N$ days" represents the number of measurements matching the coincidence criteria.

\begin{tabular}{|c|c|c|c|c|c|c|c|}
\hline \multirow{2}{*}{$\begin{array}{l}\text { Station } \\
\text { Ankara }\end{array}$} & \multicolumn{2}{|c|}{ Location } & \multirow{2}{*}{$\begin{array}{r}N \text { days } \\
50\end{array}$} & \multirow{2}{*}{$\begin{array}{l}\text { Station } \\
\text { Tateno }\end{array}$} & \multicolumn{2}{|c|}{ Location } & \multirow{2}{*}{$\begin{array}{r}N \text { days } \\
4\end{array}$} \\
\hline & $39.97^{\circ} \mathrm{N}$ & $32.86^{\circ} \mathrm{E}$ & & & $36.10^{\circ} \mathrm{N}$ & $140.10^{\circ} \mathrm{E}$ & \\
\hline Aquila & $42.38^{\circ} \mathrm{N}$ & $13.31^{\circ} \mathrm{E}$ & 11 & Uccle & $50.80^{\circ} \mathrm{N}$ & $4.35^{\circ} \mathrm{E}$ & 390 \\
\hline Barajas & $40.47^{\circ} \mathrm{N}$ & $3.58^{\circ} \mathrm{W}$ & 139 & Ushuaia & $54.85^{\circ} \mathrm{S}$ & $68.31^{\circ} \mathrm{W}$ & 2 \\
\hline Beijing & $39.54^{\circ} \mathrm{N}$ & $117.12^{\circ} \mathrm{E}$ & 7 & Valentia & $51.93^{\circ} \mathrm{N}$ & $10.25^{\circ} \mathrm{W}$ & 33 \\
\hline Bratts Lake & $50.20^{\circ} \mathrm{N}$ & $104.70^{\circ} \mathrm{W}$ & 56 & Wallops Island & $37.90^{\circ} \mathrm{N}$ & $75.70^{\circ} \mathrm{W}$ & 15 \\
\hline Broadmeadows & $37.69^{\circ} \mathrm{S}$ & $144.94^{\circ} \mathrm{E}$ & 19 & & & & \\
\hline Churchill & $58.74^{\circ} \mathrm{N}$ & $94.07^{\circ} \mathrm{W}$ & 46 & Hanoi & $21.02^{\circ} \mathrm{N}$ & $105.80^{\circ} \mathrm{E}$ & 16 \\
\hline De Bilt & $52.10^{\circ} \mathrm{N}$ & $5.18^{\circ} \mathrm{E}$ & 104 & Hilo & $19.43^{\circ} \mathrm{N}$ & $155.04^{\circ} \mathrm{W}$ & 62 \\
\hline Edmonton & $53.55^{\circ} \mathrm{N}$ & $114.11^{\circ} \mathrm{W}$ & 2 & Hong Kong & $22.31^{\circ} \mathrm{N}$ & $114.17^{\circ} \mathrm{E}$ & 93 \\
\hline Egbert & $44.23^{\circ} \mathrm{N}$ & $79.78^{\circ} \mathrm{W}$ & 57 & Irene & $25.90^{\circ} \mathrm{S}$ & $28.22^{\circ} \mathrm{E}$ & 4 \\
\hline Goose Bay & $53.31^{\circ} \mathrm{N}$ & $60.36^{\circ} \mathrm{W}$ & 98 & Java & $7.50^{\circ} \mathrm{S}$ & $112.60^{\circ} \mathrm{E}$ & 6 \\
\hline Hohenpeissenberg & $47.80^{\circ} \mathrm{N}$ & $11.00^{\circ} \mathrm{W}$ & 319 & Kuala Lumpur & $2.73^{\circ} \mathrm{N}$ & $101.70^{\circ} \mathrm{E}$ & 5 \\
\hline Huntsville & $34.72^{\circ} \mathrm{N}$ & $86.64^{\circ} \mathrm{W}$ & 9 & Nairobi & $1.27^{\circ} \mathrm{S}$ & $36.80^{\circ} \mathrm{E}$ & 78 \\
\hline Kelowna & $49.93^{\circ} \mathrm{N}$ & $119.40^{\circ} \mathrm{W}$ & 124 & Naha & $26.20^{\circ} \mathrm{N}$ & $127.70^{\circ} \mathrm{E}$ & 0 \\
\hline Lauder & $45.04^{\circ} \mathrm{S}$ & $169.68^{\circ} \mathrm{E}$ & 5 & Natal & $5.49^{\circ} \mathrm{S}$ & $35.80^{\circ} \mathrm{W}$ & 64 \\
\hline Legionowo & $52.40^{\circ} \mathrm{N}$ & $20.97^{\circ} \mathrm{E}$ & 133 & Pago Pago & $14.23^{\circ} \mathrm{S}$ & $170.56^{\circ} \mathrm{W}$ & 13 \\
\hline Lindenberg & $52.21^{\circ} \mathrm{N}$ & $14.12^{\circ} \mathrm{E}$ & 148 & Panama & $7.75^{\circ} \mathrm{N}$ & $80.25^{\circ} \mathrm{W}$ & 2 \\
\hline Macquarie Island & $54.50^{\circ} \mathrm{S}$ & $158.94^{\circ} \mathrm{E}$ & 1 & Reunion & $21.06^{\circ} \mathrm{S}$ & $55.48^{\circ} \mathrm{E}$ & 87 \\
\hline Payerne & $46.49^{\circ} \mathrm{N}$ & $6.57^{\circ} \mathrm{E}$ & 389 & Samoa & $14.23^{\circ} \mathrm{S}$ & $170.56^{\circ} \mathrm{W}$ & 3 \\
\hline Prague & $50.01^{\circ} \mathrm{N}$ & $14.45^{\circ} \mathrm{E}$ & 143 & San Cristóbal & $0.92^{\circ} \mathrm{S}$ & $89.60^{\circ} \mathrm{W}$ & 24 \\
\hline Sapporo & $43.10^{\circ} \mathrm{N}$ & $141.30^{\circ} \mathrm{E}$ & 12 & Santa Cruz & $28.46^{\circ} \mathrm{N}$ & $16.26^{\circ} \mathrm{W}$ & 2 \\
\hline Stony Plain & $53.55^{\circ} \mathrm{N}$ & $114.11^{\circ} \mathrm{W}$ & 57 & Watukosek & $7.50^{\circ} \mathrm{S}$ & $112.60^{\circ} \mathrm{E}$ & 16 \\
\hline
\end{tabular}
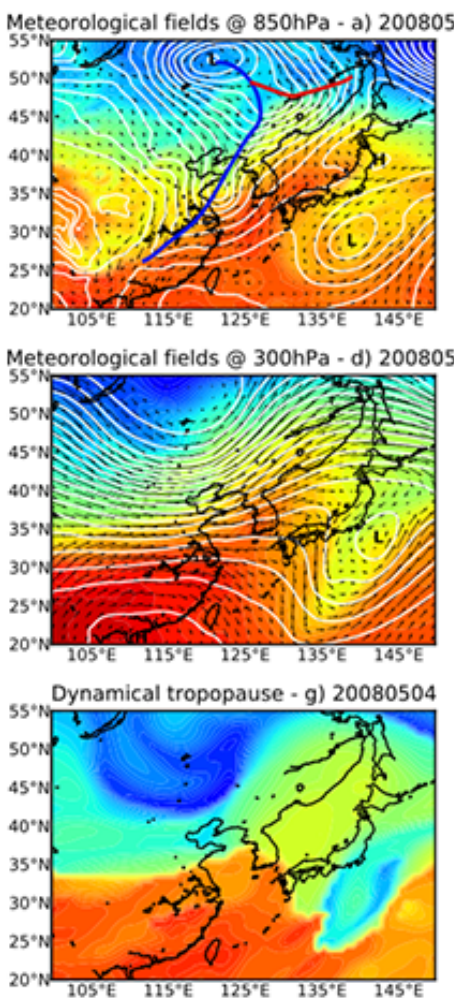

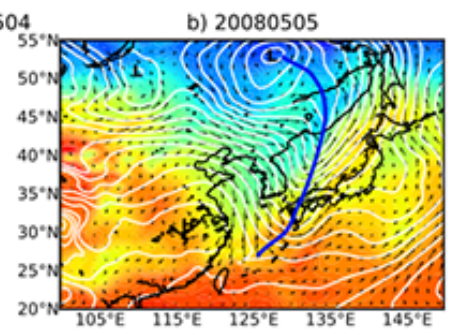

e) 20080505

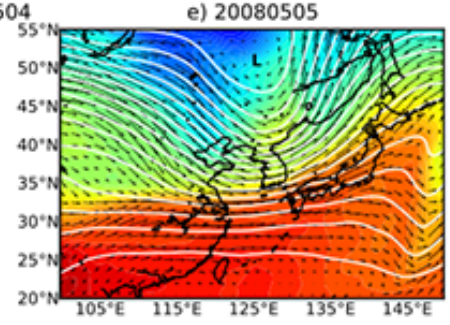

h) 20080505

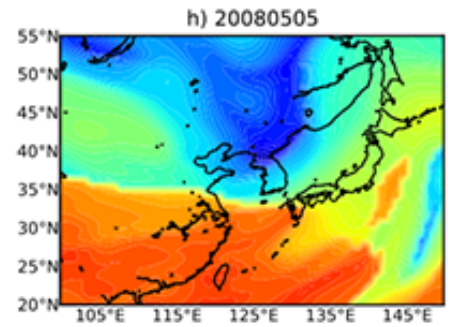

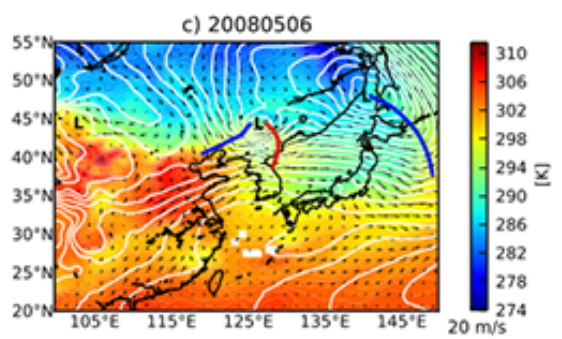

f) 20080506

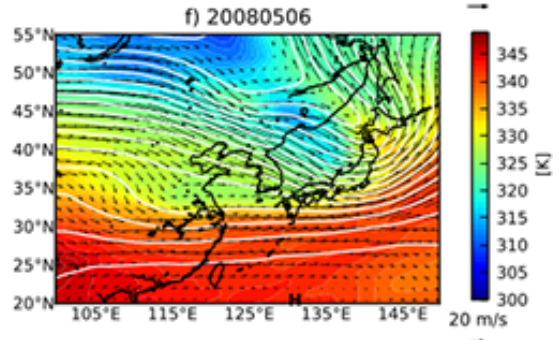

i) 20080506

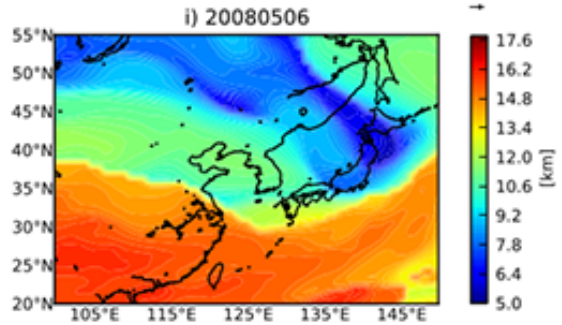

Figure 1. Meteorological situation given at (a-c) $850 \mathrm{hPa}$ and (d-f) $300 \mathrm{hPa}$ from 4 to 6 May 2008 as well as (g-i) the dynamical tropopause. All the meteorological variables are derived from the ERA-Interim reanalysis. The coloured areas in (a-f) represent the equivalent potential temperature and the white contours the geopotential height. The "L" and " $\mathrm{H}$ " symbols represent the centre of lows and highs respectively. Horizontal winds are also plotted. The cold and warm fronts are displayed in blue and red respectively on the top panel. 

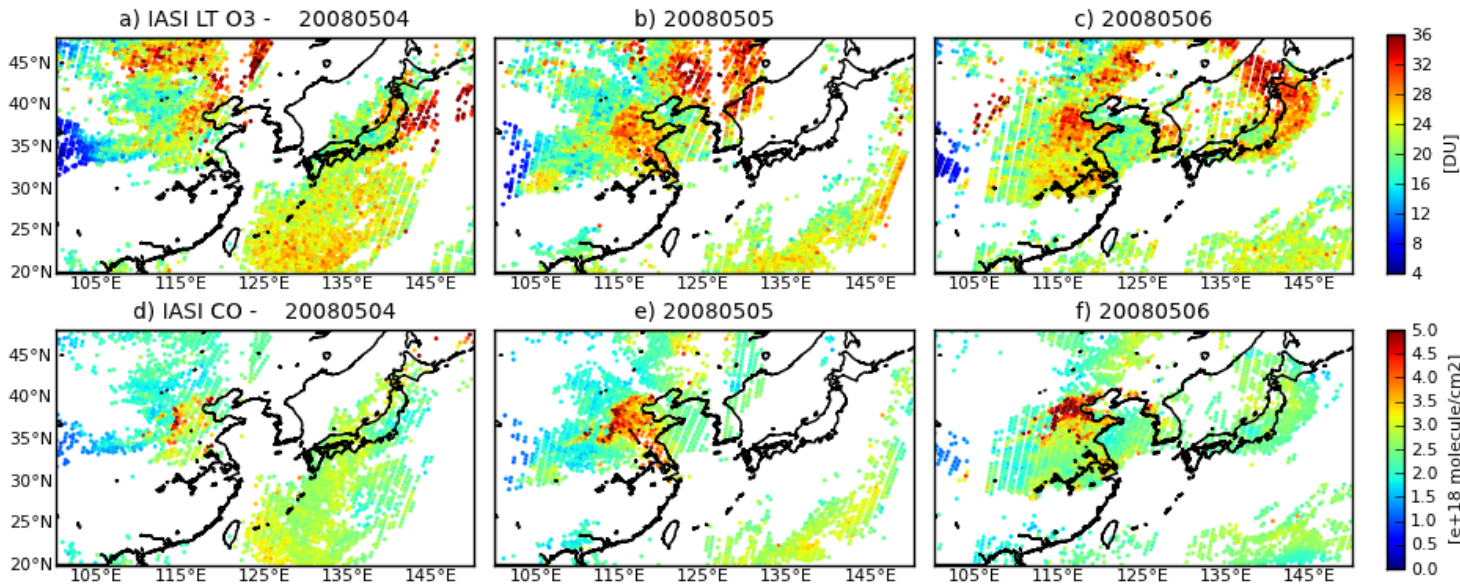

g) IASI UT O3 - 20080504 e) 20080505

f) 20080506

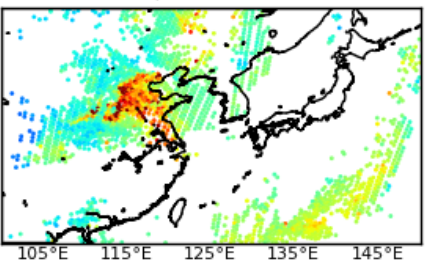

h) 20080505

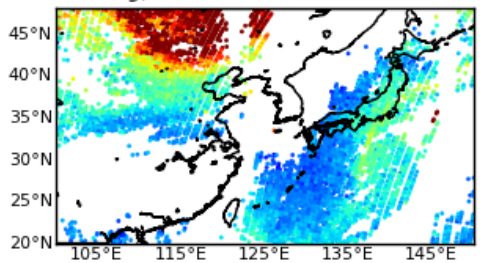

j) PV $300-500 \mathrm{hPa}-20080504$
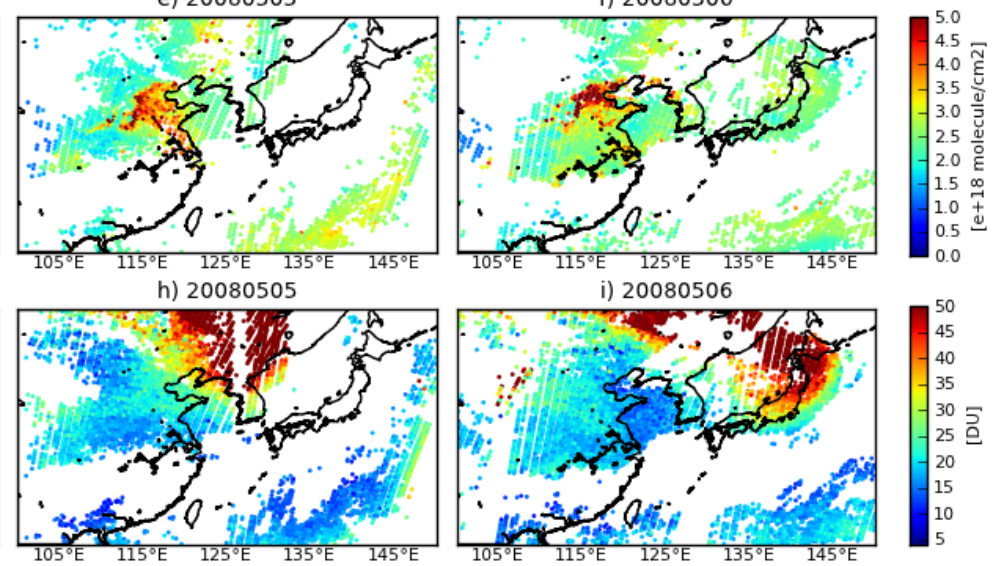

i) 20080506

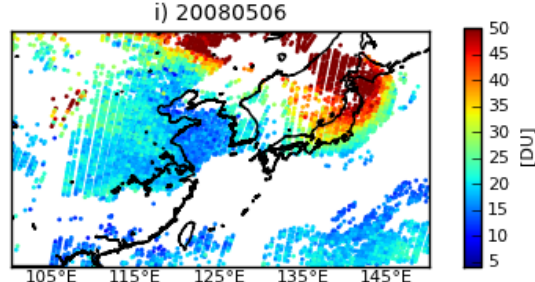

k) 20080505
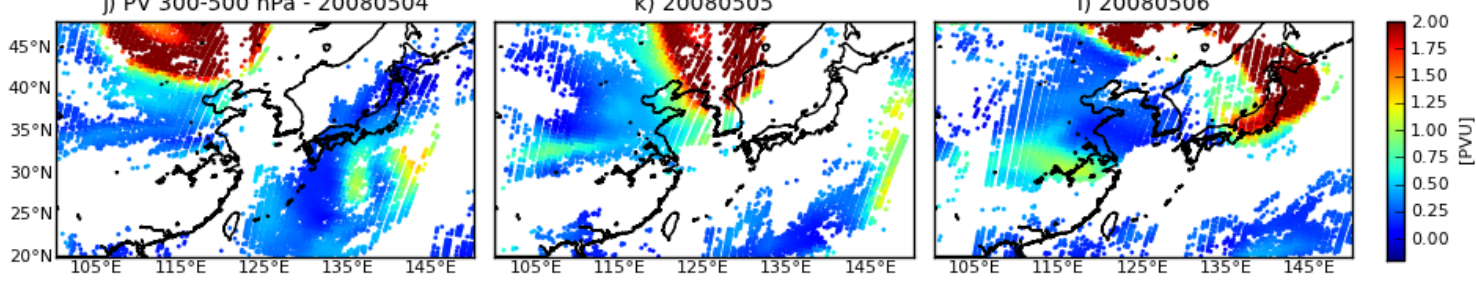

Figure 2. Panels (a-c): lower-tropospheric ozone columns (surface to $6 \mathrm{~km}$ a.s.1.) retrieved from IASI from 4 to 6 May 2008; panels (d-f): total CO columns retrieved from IASI; panels (g-i): upper-tropospheric ozone columns (6 to $12 \mathrm{~km}$ a.s.l.) retrieved from IASI; panels (j-l): potential vorticity (PV) from ERA5 Interim reanalysis averaged between 300 and $500 \mathrm{hPa}$.

Table 2. Validation results for the lower-tropospheric ozone columns. The bias (IASI-sonde), the rms and the correlation coefficient are provided for all stations listed. The bias and the rms are given in DU, with the percentage in parenthesis.

\begin{tabular}{lrrr}
\hline Station & Bias & rms & $R$ \\
\hline All stations & $-0.6(2.8)$ & $2.8(13.7)$ & 0.70 \\
East Asia & $-2.2(-9.5)$ & $2.7(11.6)$ & 0.70 \\
Beijing & $-2.6(-9.0)$ & $2.6(9.0)$ & 0.71 \\
Sapporo & $0.8(3.9)$ & $3.9(19.8)$ & 0.68 \\
Tateno & $-2.6(-12.1)$ & $2.3(10.8)$ & 0.60 \\
Hong Kong & $-2.6(-10.9)$ & $2.2(9.6)$ & 0.67 \\
\hline
\end{tabular}

served enhancement in the lower-tropospheric column (surface $6 \mathrm{~km}$ ) arises from (1) the actual (reversible) transfer of ozone to the free troposphere, (2) the definition of the LT columns by itself, (3) the limited vertical resolution of the retrieval and the associated smoothing of the vertical profile. Indeed, the LT columns are defined as the columns from the surface up to $6 \mathrm{~km}$. Consequently, when the tropopause is low (below $9 \mathrm{~km}$ ), the LT column arithmetically includes layers with upper-tropospheric characteristics. Moreover, due to the limited vertical resolution of the retrieval and the associated smoothing of the vertical profile, the lower-tropospheric column is partly contaminated by ozone from outside the column altitude boundaries, as discussed in Sect. 2.2. This may contribute to an overestimation of the lower-tropospheric column. However, it is difficult to estimate this overestimation in our case because no ozonesonde observations were available along the path of the low.

We show with this case study that having the IASI UT and LT ozone columns allows us to determine those regions affected by the subsiding transfer of ozone occurring behind the frontal area and whether the lower troposphere is affected. We will now examine if and how IASI can be used to characterize irreversible STEs. The analysis of the PV distribution at different pressure levels allows the identification of the region in the vicinity of the low where STE occurs. In the case study from 4 to 6 May 2008, we identify two regions with high PV values down to 600 or $500 \mathrm{hPa}$ in the path of the low (not shown): one on the east coast of Korea on 5 May 

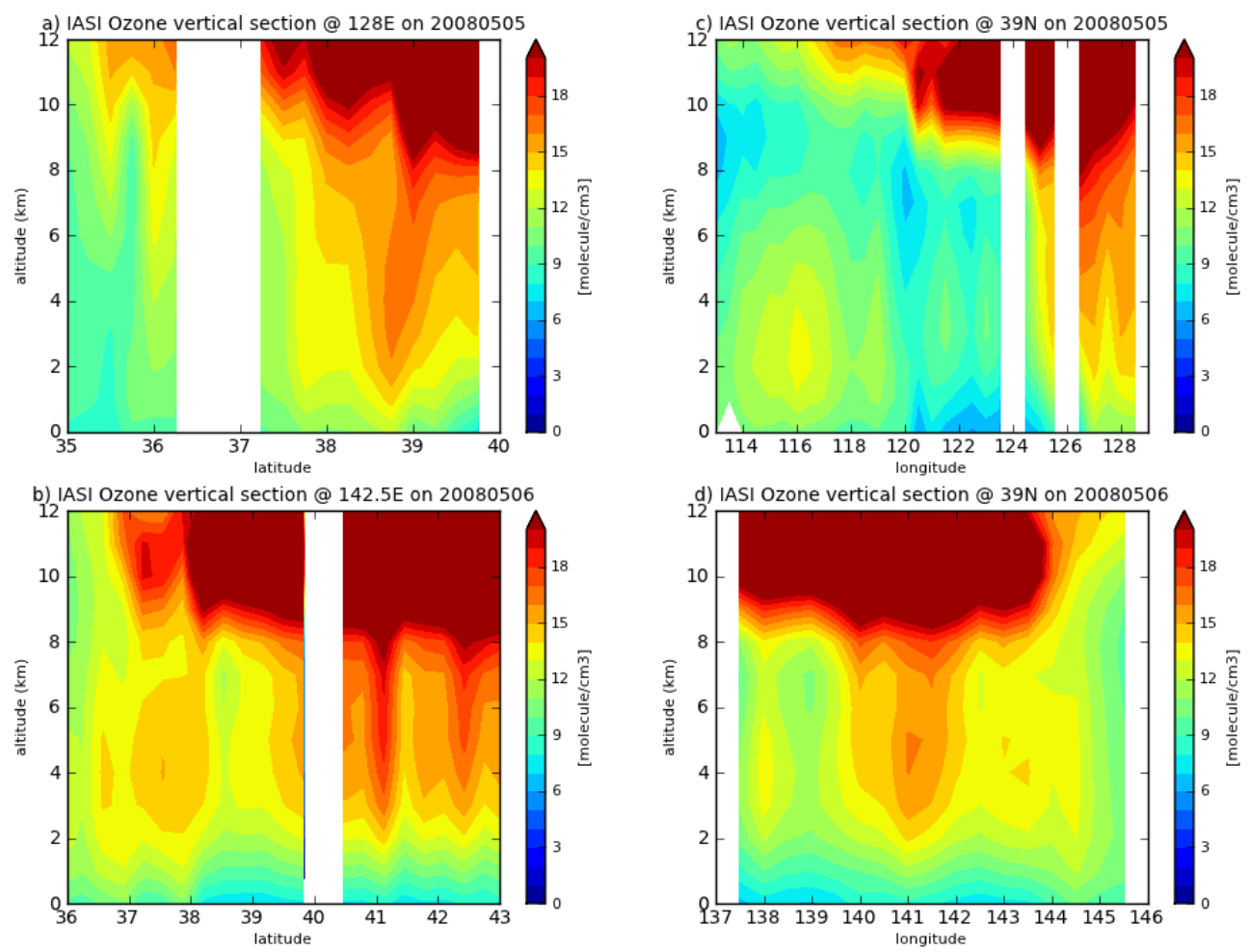

Figure 3. Vertical section of ozone concentration (in molecule $\mathrm{cm}^{-3}$ ) retrieved from IASI along specific longitudes $-128^{\circ} \mathrm{E}$ on $5 \mathrm{May} 2008$ (a), $142.5^{\circ} \mathrm{E}$ on 6 May 2008 (b) - and along specific latitudes $-39^{\circ} \mathrm{N}$ on 5 May 2008 (c) and 6 May 2008 (d). The longitudinal (latitudinal) sections are computed over $1^{\circ}$ around the specific longitude (latitude) with a $0.25^{\circ}$ resolution in latitude (longitude).

$\left(\sim 39^{\circ} \mathrm{N}, 128^{\circ} \mathrm{E}\right)$ and one offshore to the northeast of Tokyo $\left(\sim 39^{\circ} \mathrm{N}, 142.5^{\circ} \mathrm{E}\right)$. The STE is situated on the southeast flank of the low-pressure system, behind and in the southern part of the cold front in the two cases. Figure 3 displays the longitudinal and latitudinal vertical section of ozone at $128^{\circ} \mathrm{E}$ and $39^{\circ} \mathrm{N}$ for 5 May (top) and at $142.5^{\circ} \mathrm{E}$ and $39^{\circ} \mathrm{N}$ for 6 May (bottom). On 5 May, strong stratospheric intrusion of ozone is observed between 38 and $39^{\circ} \mathrm{N}$ and between 125 and $130^{\circ} \mathrm{E}$. The vertical section at $128^{\circ} \mathrm{E}$ shows that the free and lower troposphere are still connected to the polar UTLS reservoir that day. On 6 May, a stratospheric intrusion is observed between 36 and $38^{\circ} \mathrm{N}$ and between 140 and $143^{\circ} \mathrm{E}$. The vertical section along $142^{\circ} \mathrm{E}$ shows that the enhanced ozone in the lower troposphere (below $7 \mathrm{~km}$ ) is partly disconnected from the polar UTLS reservoir. Backtrajectories performed with the HYSPLIT (Hybrid Single Particle Lagrangian Integrated Trajectory) model (Draxler and Rolph, 2015; Rolph, 2015) show that the $3 \mathrm{~km}$ altitude air masses located in this area originate at altitudes between 5 and $7 \mathrm{~km}$ the day before in north China and Inner Mongolia (Fig. S1 in the Supplement). The tropopause height was around 7-8 km on 5 May 2008 for these regions (Fig. 1h). This means that the air masses reaching the area northeast of Tokyo at $3 \mathrm{~km}$ on 6 May have a UTLS origin and transport ozone-rich air into the lower troposphere. Thus, we show that the down- ward transport from the UTLS affects ozone concentrations in the lower troposphere for specific regions on the southeastern flank of the weather system, whereas the perturbation of the tropopause associated with this system influences upperand lower-tropospheric ozone over larger areas in the vicinity of the low.

\subsection{Influence of the high-pressure system on tropospheric ozone distribution over the North China Plain (NCP)}

On 5 May 2008, an anticyclone forms over central east China and the North China Plain. The northwesterly winds reaching the NCP change progressively to southwesterly winds from 4 to 6 May with low winds and then a stagnant situation on 5 May (Fig. 1a-c). This, associated with low cloud coverage and increasing radiation, is a situation favourable to the accumulation of primary pollutants over the NCP and to the photochemical production of ozone due to both local emissions and the regional transport of pollutants. The question here is how IASI is able to describe this situation. The CO columns observed with IASI show enhanced values over the NCP on 5 and 6 May (Fig. 2e and f). Considering $\mathrm{CO}$ as a pollution tracer, enhanced IASI CO columns can be used to evaluate the build-up of pollutants. Concomitantly, lower-tropospheric ozone columns as large as 
$30 \mathrm{DU}$ are observed (Fig. 2b and c). A significant spatial correlation $(r=0.6)$ is calculated between $\mathrm{CO}$ and lowertropospheric ozone columns for a square region including the NCP $\left(35-41^{\circ} \mathrm{N}, 114-122^{\circ} \mathrm{E}\right)$ on 5 May. In addition, the upper-tropospheric ozone column does not show enhanced values over the NCP for these 2 days (Fig. $2 \mathrm{~h}$ and i). The analysis of the vertical section of ozone distribution on 5 May shows that the large ozone concentrations in the Beijing region (Fig. 3, $\sim 39^{\circ} \mathrm{N}$ and $\sim 116^{\circ} \mathrm{E}$ ) and across the NCP are retrieved below $6 \mathrm{~km}$ and are disconnected from the UTLS region. The maximal values of ozone are retrieved between 2 and $3 \mathrm{~km}$ over Beijing (Fig. 3) in agreement, considering the vertical sensitivity and resolution of IASI, with in situ measurements, which frequently report high ozone concentrations at an altitude of 1.5-2 km above Beijing during April-May (Huang et al., 2015). This associated with the correlation with $\mathrm{CO}$ suggests that the enhanced ozone observed with IASI is mainly due to the photochemical transformation of primary pollutants emitted over the NCP. To evaluate the degree of the photochemical production of ozone, we calculate the equivalent or mean mixing ratio corresponding to the $\mathrm{CO}$ and $\mathrm{LT} \mathrm{O}_{3}$ columns. This allows us to estimate a relative enhancement ratio of $\mathrm{O}_{3}$ to $\mathrm{CO}$ of 0.14 and 0.08 on 5 and 6 May respectively. These values are in agreement with the typical values ranging between 0 and 0.3 reported over east Asia by Tanimoto et al. (2008). The estimated enhancement ratio remains quite low, suggesting an early stage of ozone production.

\section{Case study of 11-16 May 2008: combined contributions of anthropogenic and stratospheric sources over the NCP and pollution transport}

A second episode of high ozone is observed in the lower troposphere over the North China Plain (NCP) from 11 to 16 May 2008. This episode is associated with a cut-off lowpressure system forming on 11 May over Inner Mongolia and moving east on subsequent days. From 14 May, the meteorological regime changes over the NCP with warmer air masses settling within an anticyclonic situation. In this section, we examine the influence of the meteorological situation on the distribution of lower- and upper-tropospheric ozone with a particular focus on the NCP. Figure 4 describes the meteorological situation for the entire period. Figures 5 and 6 display the lower- and upper-tropospheric ozone columns and the total CO columns observed with IASI.

\subsection{1-13 May: the NCP under the direct influence of the cut-off low}

On 11 May 2008, a cut-off low forms over Inner Mongolia (Fig. 4a). The cut-off low is not yet completely dissociated from the polar reservoir. A band of upper-tropospheric columns larger than $40 \mathrm{DU}$ is observed by IASI between 35 and $45^{\circ} \mathrm{N}$ (Fig. $5 \mathrm{~g}$ ). As seen in Sect. 4 , it indicates that the region is under the influence of subsiding ozone. The lowertropospheric ozone columns do not show a clear enhancement for the same latitude band. On that day, subsiding ozone affects the lower-tropospheric ozone only moderately.

On 12 May 2008, the cut-off low is well dissociated from the western current and its centre reaches the Bohai Sea (Fig. 4b). Upper-tropospheric ozone columns larger than $45 \mathrm{DU}$ are retrieved all around the cut-off low. Lowertropospheric ozone columns larger than $32 \mathrm{DU}$ are observed especially in the southwestern part of the low, just above the NCP (Fig. 5b). The analysis of the vertical section of ozone at $117^{\circ} \mathrm{E}$ (Fig. 7a) shows that the subsiding transfer of ozone due to the tropopause perturbation strongly affects lower-tropospheric ozone north of $33^{\circ} \mathrm{N}$. At $32^{\circ} \mathrm{N}$, the ozone enhancement observed in the lower troposphere is not connected to the UTLS reservoir, suggesting a possible photochemical origin for this enhancement. IASI CO columns are also enhanced in the NCP region and partly correlated with the enhanced ozone columns (Fig. 5e). This indicates that pollution likely plays a concomitant role in the ozone enhancement in that case.

On 13 May 2008, the centre of the cut-off low moves slightly to the east and reaches the Yellow Sea (Fig. 4c). As for the previous day, large upper- and lower-tropospheric ozone columns are observed with IASI in the vicinity of the low (Fig. 5c and i). The two columns are slightly smaller than the day before over the NCP. The analysis of the vertical section of ozone at $115^{\circ} \mathrm{E}$ (Fig. $7 \mathrm{~b}$ ) shows that the subsiding transfer of ozone due to the tropopause perturbation is less effective than the previous day. Even if the lowertropospheric ozone remains partly connected to the UTLS reservoir north of $33^{\circ} \mathrm{N}$, secondary maxima are observed at $\sim 4 \mathrm{~km}$ of altitude, suggesting that an additional source of ozone may contribute to the LT ozone enhancement. South of $33^{\circ} \mathrm{N}$ the ozone enhancement is clearly located in the lower troposphere. The good spatial correlation of LT ozone enhancement and the strong $\mathrm{CO}$ enhancement observed all over the NCP (Fig. 5f) confirms that pollution plays a concomitant role in explaining the ozone distribution in the lower troposphere over the NCP for this day.

\subsection{May: transition from a cyclonic to an anticyclonic situation}

On 14 May 2008, the cut-off low shifts to the Sea of Japan (Fig. 4d). A large area including north China, Korea, and reaching Japan shows upper-tropospheric columns larger than $40 \mathrm{DU}$ (Fig. 6g), which indicates the region is under the influence of subsiding ozone. Within this area, the largest LT ozone columns are observed in an area less extended and situated on the southeastern flank of the low, mainly over the Sea of Japan (Fig. 6a). The lower troposphere is then certainly under the influence of the UTLS. 

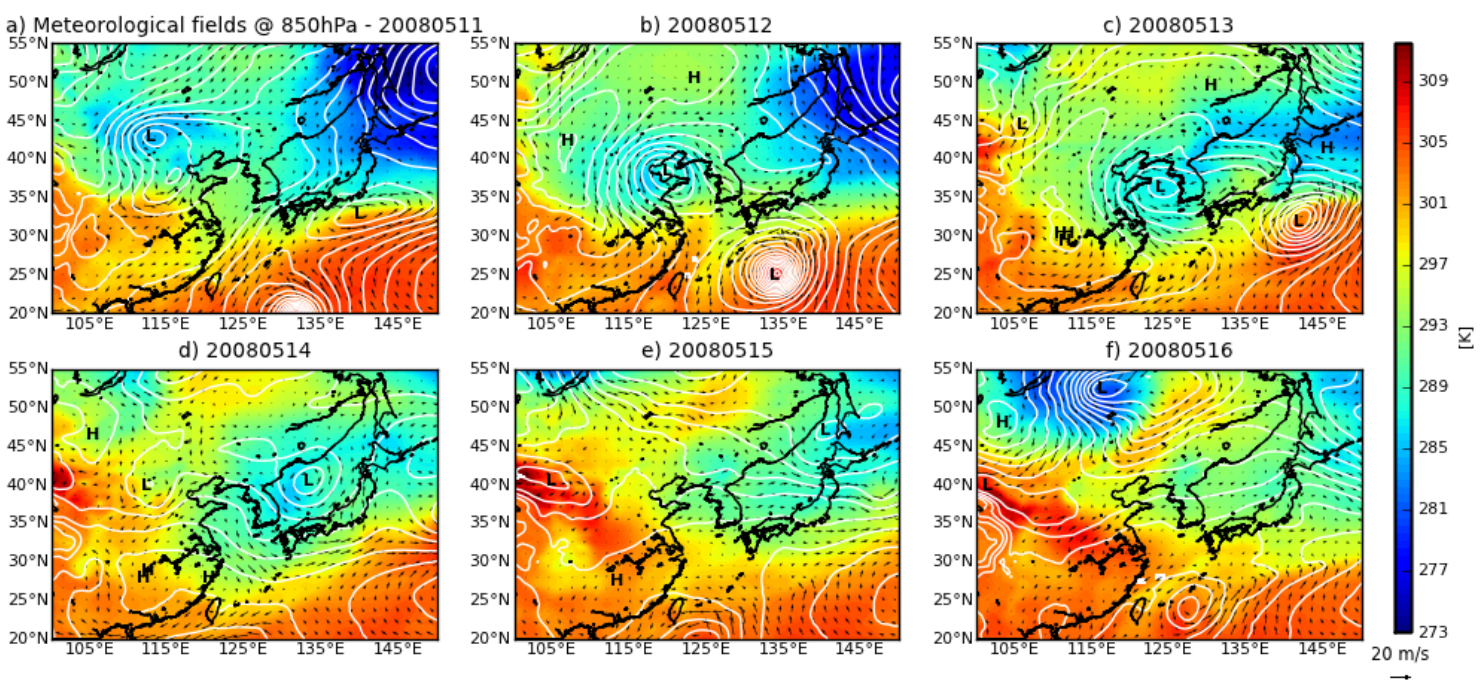

Figure 4. Meteorological situation given at $850 \mathrm{hPa}$ from 11 to 16 May 2008. The coloured areas represent the equivalent potential temperature and the white contours the geopotential height. The "L" and "H" symbols represent the centre of lows and highs respectively. Horizontal winds are also plotted.

a) IASI LT O3 - 20080511

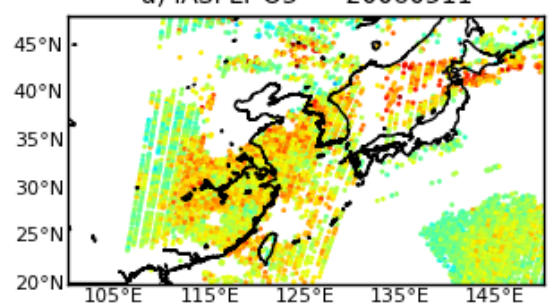

d) IASI CO - 20080511

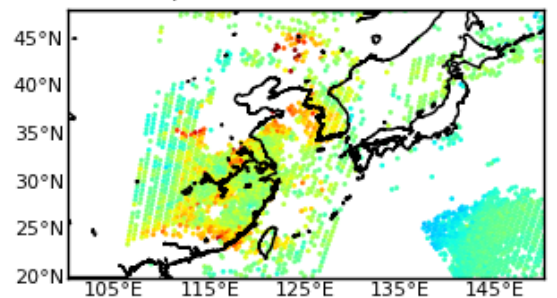

g) IASI UT O3 - 20080511

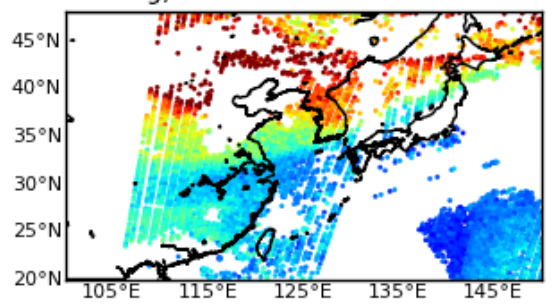

b) 20080512

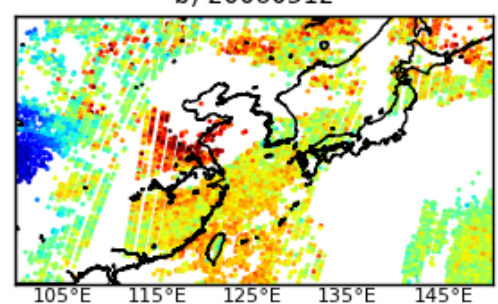

e) 20080512

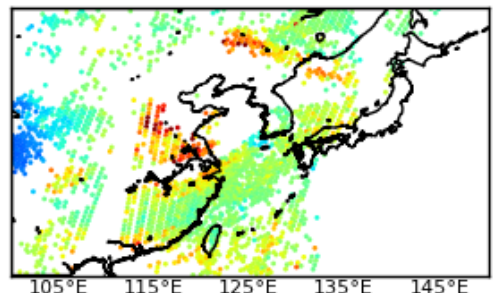

h) 20080512

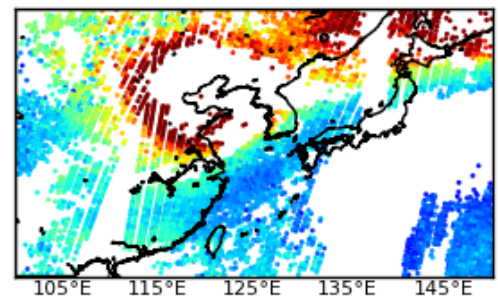

c) 20080513

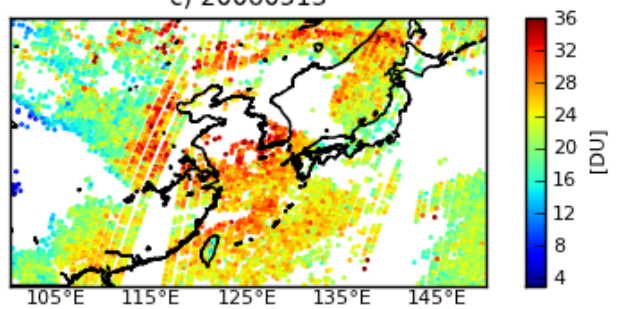

f) 20080513

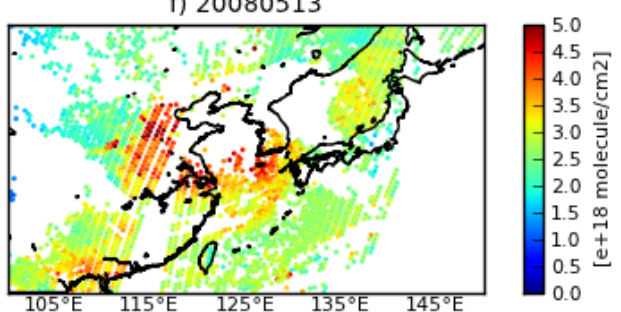

i) 20080513

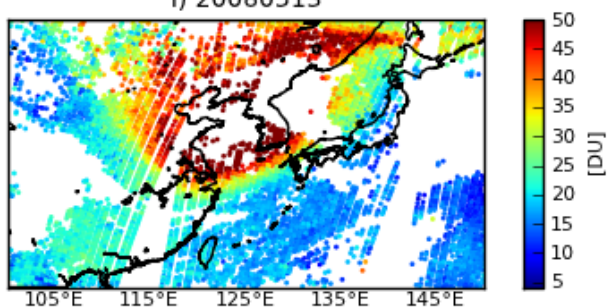

Figure 5. Panels (a-c): lower-tropospheric ozone columns (surface to $6 \mathrm{~km}$ a.s.l) retrieved from IASI from 11 to 13 May 2008 . Panels (d-f): total CO columns retrieved from IASI. Panels (g-i): upper-tropospheric ozone columns (6 to $12 \mathrm{~km}$ a.s.1.) retrieved from IASI.

Over China, an anticyclonic situation starts to develop south of the NCP inducing a change in the wind regime and warmer conditions from 14 May (Fig. 4d). Enhanced CO columns and lower-tropospheric ozone columns are retrieved with IASI over the NCP (Fig. 6a and d) with moderate UT ozone columns. The analysis of the vertical section of ozone concentrations at $35^{\circ} \mathrm{N}$ shows that very large ozone concentrations are retrieved for the entire free and upper troposphere in the eastern part of the section (Fig. 7c). This corresponds to the region over the Sea of Japan under the direct influence 
a) IASI LT O3 - 20080514

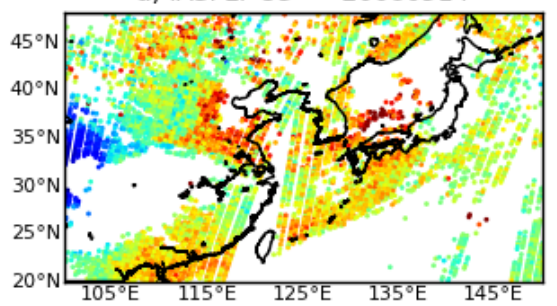

d) IASI CO - 20080514

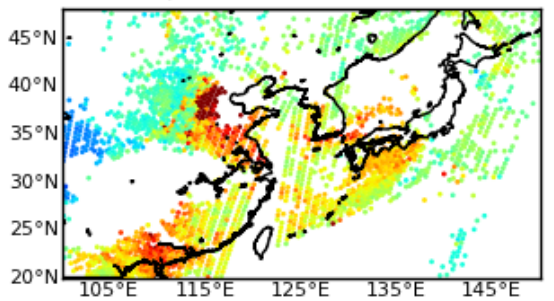

g) IASI UT O3 - 20080514

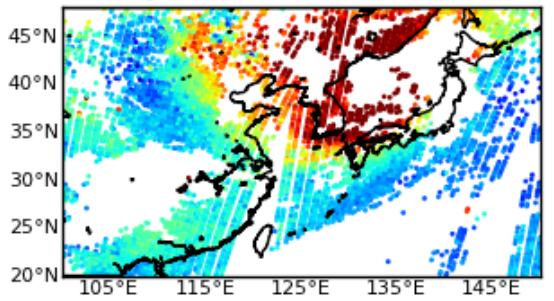

b) 20080515

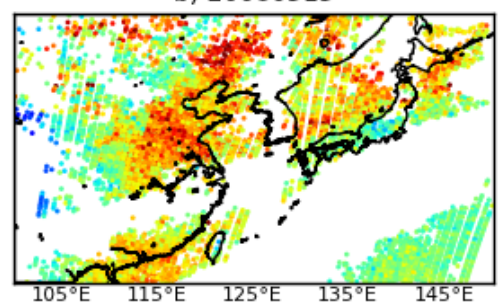

e) 20080515

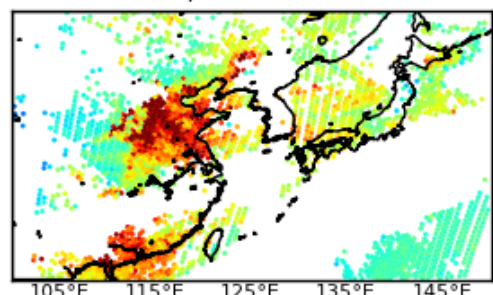

h) 20080515

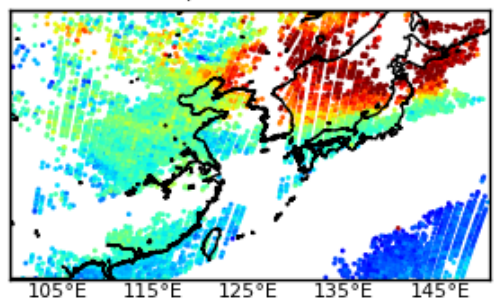

c) 20080516

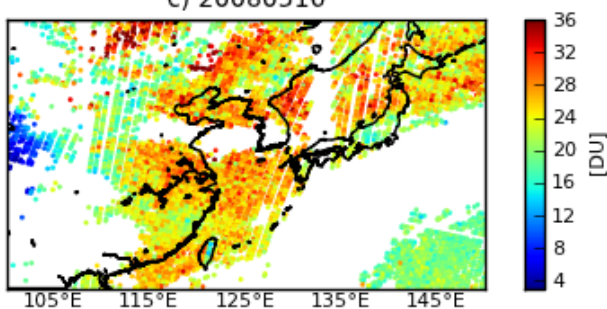

f) 20080516

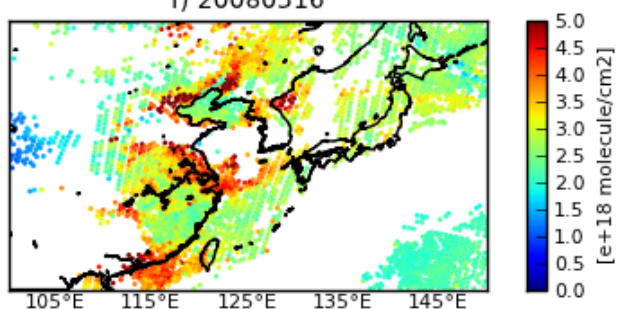

i) 20080516

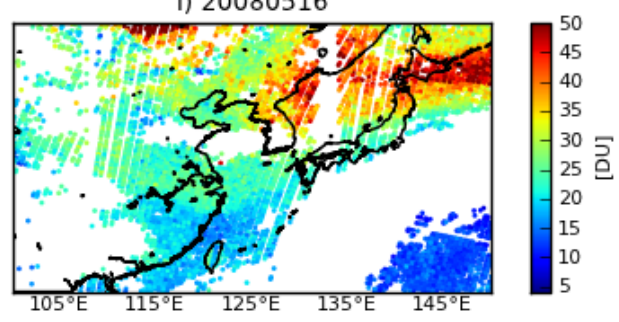

Figure 6. Same as Fig. 5 but for 14 to 16 May 2008.

of the cut-off low and then greatly influenced by the UTLS. The situation is different over the NCP: ozone concentrations in the upper troposphere are moderate and a distinct maximum in the lower troposphere is clearly visible. This, associated with $\mathrm{CO}$ enhancement over the NCP in good spatial correlation with LT ozone, indicates that the ozone enhancement observed with IASI over the NCP is of anthropogenic origin and related to the photochemical production of ozone. On that day, the estimated enhancement ratio of $\mathrm{O}_{3}$ to $\mathrm{CO}$ is 0.11 , in agreement with the enhancement ratio calculated for the previous case study.

\subsection{5-16 May: the NCP under anticyclonic influence}

On 15 and 16 May 2008, strong enhancements of CO and lower-tropospheric ozone are observed with IASI over the entire NCP (Fig. 6b-c and e-f). Both $\mathrm{CO}$ and $\mathrm{O}_{3}$ increase compared to the previous day. The anticyclone is firmly settled over China, leading to a stagnant situation with low winds all over the NCP (Fig. 4e). This situation is favourable to the accumulation of pollutant and then to the photochemical production of ozone. Figure $7 \mathrm{~d}$ shows the vertical section of ozone concentrations retrieved with IASI at $37^{\circ} \mathrm{N}$. The ozone enhancement is located below $4 \mathrm{~km}$, especially between 115 and $116^{\circ} \mathrm{E}$, in agreement with the findings of Sect. 4.2. This, with CO enhancement, indicates that the ozone enhancement is due to photochemical production from pollutants emitted in the NCP. In this case of stronger $\mathrm{CO}$ enhancement, the enhancement ratio of $\mathrm{O}_{3}$ to $\mathrm{CO}(0.09$ on 15 May and 0.06 on 16 May) decreases compared to the previous days.

\subsection{Evidence of transboundary transport within the cut-off low}

On 13 and 14 May, large $\mathrm{CO}$ and $\mathrm{O}_{3}$ columns are retrieved from IASI over the Yellow Sea and over the Sea of Japan on the southern flank of the cut-off low-pressure system (Figs. 5c and 6a). Fairly strong westerly winds are present at $850 \mathrm{hPa}$ in the same region, suggesting a possible advection of air masses from the NCP towards Japan associated with the weather system (Fig. 4c and d). In order to assess whether the weather system may have contributed to transporting the pollutants $\left(\mathrm{O}_{3}\right.$ and $\left.\mathrm{CO}\right)$, we perform backtrajectories on 13 May for an area south of Korea (Fig. S2). The $3 \mathrm{~km}$ air masses originate from the boundary layer over the $\mathrm{NCP}$ on 11 May. They are uplifted and transported at an altitude of between 3 and $4 \mathrm{~km}$ on subsequent days (Fig. S2). In order to investigate whether the pollutant uplifting on 11 May occurs over a region more extended than those shown in Fig. S2, we examined two meteorological variables that indicate a possible ascending motion of air masses: the convective available potential energy (CAPE) and the vertical velocity. Figure 8 shows that CAPE is significant on the in- 

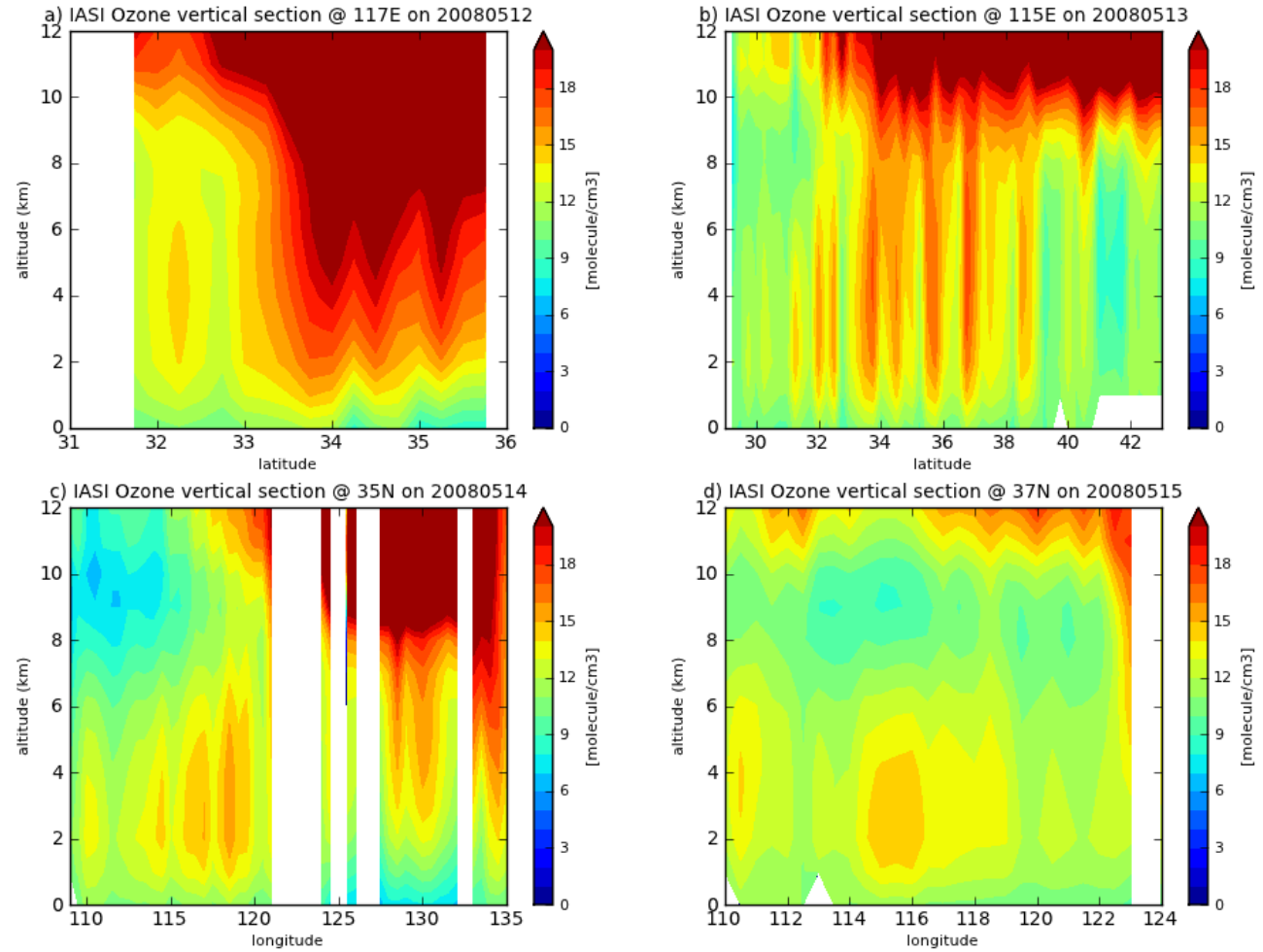

Figure 7. Vertical section of ozone concentration (in molecule $\mathrm{cm}^{-3}$ ) retrieved from IASI along specific longitudes $-(\mathbf{a}) 117^{\circ} \mathrm{E}$ on $12 \mathrm{May}$ 2008, (b) $115^{\circ} \mathrm{E}$ on 13 May 2008 - and along specific latitudes - (c) $35^{\circ} \mathrm{N}$ on 14 May 2008, (d) $37^{\circ} \mathrm{N}$ on 15 May 2008 . The longitudinal (latitudinal) sections are computed over $1^{\circ}$ around the specific longitude (latitude) with a $0.25^{\circ}$ resolution in latitude (longitude).
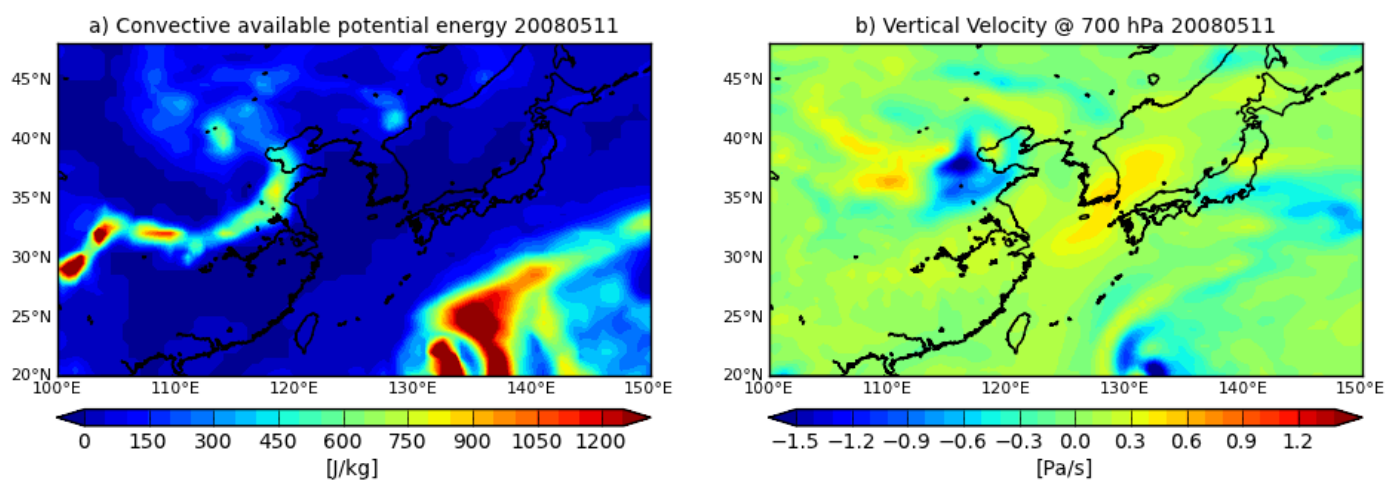

Figure 8. Convective available potential energy (a) and vertical velocity at $700 \mathrm{hPa}$ (b) from ERA-Interim reanalysis.

side eastern flank of the cut-off low and that negative vertical velocities, i.e., ascending winds, are present from the surface up to $300 \mathrm{hPa}$ (Fig. 8 shows only the vertical velocity at $700 \mathrm{hPa}$ as an example). In addition, backtrajectories performed on 11 May indicate that most of the air masses between $38-40^{\circ} \mathrm{N}$ and $116-117^{\circ} \mathrm{E}$ at $3 \mathrm{~km}$ originate from the atmospheric layers below $1 \mathrm{~km}$ and circulate over the NCP during the previous $24 \mathrm{~h}$ (Fig. S3). This shows that pollutants $\left(\mathrm{CO}\right.$ and $\mathrm{O}_{3}$ ) have been uplifted from the boundary layer into the free troposphere over the NCP and then exported towards Japan by the cut-off low. This transport pathway is relatively well known. Very recently, Ding et al. (2015) studied the uplifting and transport of $\mathrm{CO}$ in east Asia in detail. They show that the vertical transport of anthropogenic $\mathrm{CO}$ originating from the NCP is mainly carried out by frontal lifting, which can be, but is not necessarily, associated with WCB. They also pointed out the topography's additional role in the $\mathrm{CO}$ lifting over the NCP.

To complete the study, we calculate the enhancement ratio of $\mathrm{O}_{3}$ to $\mathrm{CO}$ over the NCP on 12 May, over the Yellow Sea and Korea $\left(32-36^{\circ} \mathrm{N}, 122-130^{\circ} \mathrm{E}\right)$ on $13 \mathrm{May}$, and over the Sea of Japan $\left(30-38^{\circ} \mathrm{N}, 128-140^{\circ} \mathrm{E}\right)$ on 14 May. The ratios 

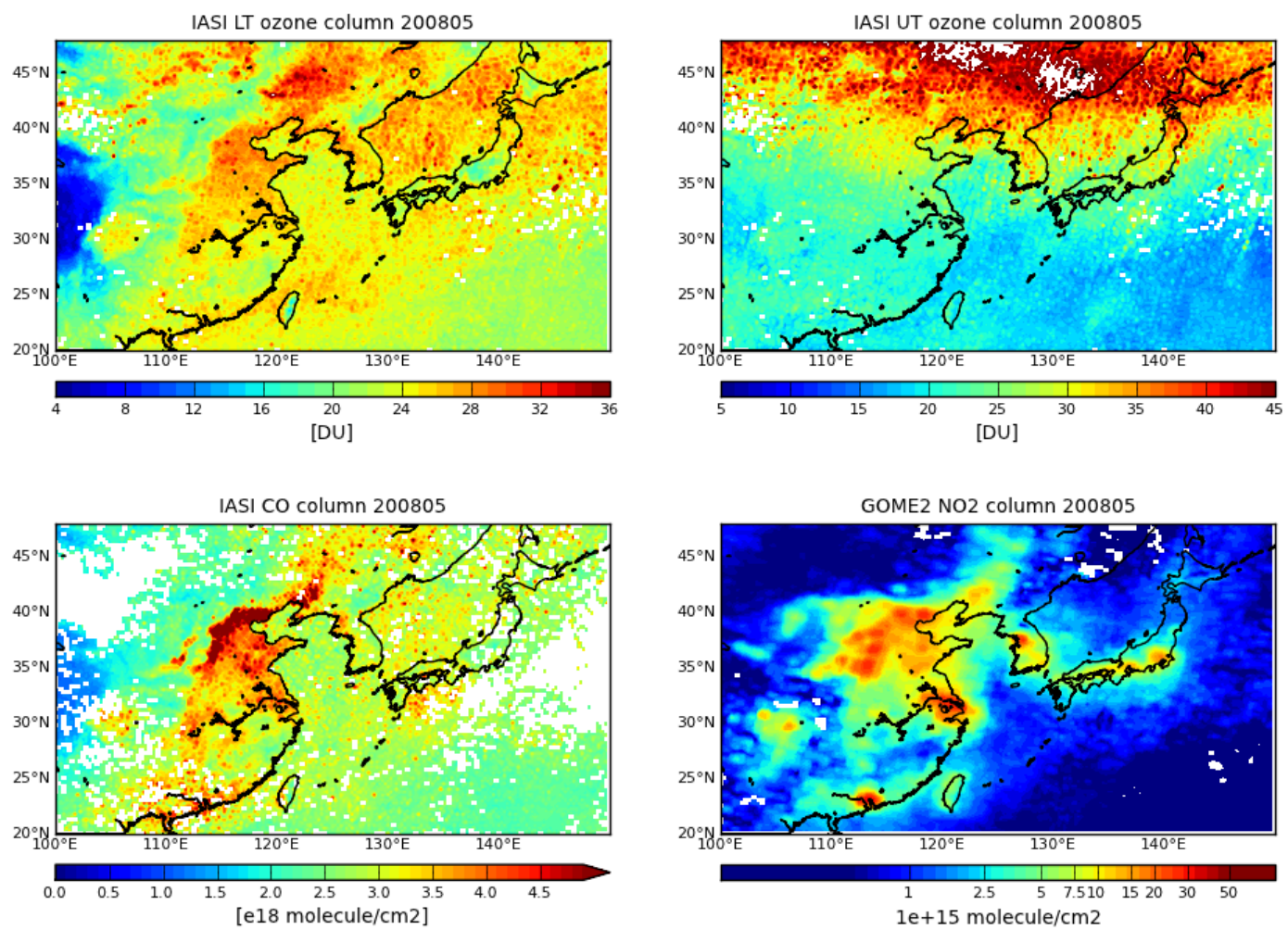

Figure 9. Monthly lower (upper left) and upper (upper right) tropospheric ozone columns observed by IASI in May 2008 as well as monthly IASI total CO columns (lower left) and GOME-2 $\mathrm{NO}_{2}$ tropospheric columns (lower right) observed in May 2008. The average is calculated for a $0.25^{\circ} \times 0.25^{\circ}$ resolution grid.

are respectively $0.16,0.21$ and 0.28 . The increase in the ratio indicates possible photochemical processing during transport. Part of the large amount of lower-tropospheric ozone is then due to the transport of ozone produced over the NCP but also to ozone produced during the transport.

\section{Role of weather systems and photochemical production on the monthly timescale}

The succession of low- and high-pressure systems plays a key role in explaining the day-to-day variations in lowertropospheric ozone over northeast Asia. In May 2008, 5 events covering 2-3 days each and leading to significant ozone enhancement in the lower troposphere have been identified. In order to evaluate the regions of influence of the frontal and cyclonic activity on the ozone distribution, we calculated monthly means of lower- and upper-tropospheric ozone columns (Fig. 9). The monthly means are given with a $0.25^{\circ} \times 0.25^{\circ}$ horizontal resolution. The upper-tropospheric ozone columns are the most affected by the ozone subsiding transfer induced by the tropopause perturbations associated with frontal activity. Looking at UT ozone columns larger than $40 \mathrm{DU}$ provides a view of the region of influence of the frontal and cyclonic activity in terms of ozone enhancement. This region is located north of $40^{\circ} \mathrm{N}$ and extends from In- ner Mongolia to north China and the north of Japan. South of $40^{\circ} \mathrm{N}$, the influence of the frontal and cyclonic activity on lower-tropospheric ozone decreases.

In order to investigate the role of pollution in enhanced lower-tropospheric ozone columns observed with IASI, we compare monthly distribution of lower-tropospheric ozone columns with the distribution of total CO columns and tropospheric $\mathrm{NO}_{2}$ columns, often used as anthropogenic source tracers (Fig. 9). The $\mathrm{NO}_{2}$ tropospheric columns are those observed by the GOME-2 instrument operating on the same satellite platform as the IASI instrument (Boersma et al., 2004) (http://www.temis.nl/airpollution/no2.html). All the regions of continental east Asia (NCP, Sichuan Basin, north China, etc.) showing large $\mathrm{NO}_{2}$ tropospheric columns and indicating large anthropogenic sources present large total $\mathrm{CO}$ columns and also large lower-tropospheric ozone columns (Fig. 9). A correlation of 0.62 over the entire domain between IASI lower-tropospheric ozone and IASI total CO suggests that anthropogenic sources significantly contribute to the ozone observed in the lower troposphere with IASI. The North China Plain, Yangtze River delta (near Shanghai) and Hubei province (Wuhan region) are the regions most impacted by pollution according to the satellite observations. Large lower-tropospheric ozone columns are observed over north China, corresponding to the industrialized Shenyang- 
Harbin axis also visible in $\mathrm{CO}$ and $\mathrm{NO}_{2}$ observations (Fig. 9). However, the ozone plume extends more to the west compared to the $\mathrm{CO}$ and $\mathrm{NO}_{2}$ plumes. This may be explained by the influence of the UTLS, which is larger all over the northern part of the domain. Lower-tropospheric columns of ozone might also be overestimated during the retrieval because the region is partly arid. Indeed, the ozone retrieval can be partly impacted in regions of low emissivity. In the southern part of the domain, enhanced lower-tropospheric ozone columns are observed in the Sichuan Basin and Guangdong province at the same time as enhanced $\mathrm{CO}$ and $\mathrm{NO}_{2}$ columns. In the latter region, closer to the equator, the distance between two successive swaths of IASI increases. Then, the spatial and temporal coverage of IASI decreases and it is less easy to follow the daily variations in ozone. Moreover, the maximum of sensitivity of IASI ozone retrievals in the tropics is usually higher in altitude (around $5 \mathrm{~km}$; Dufour et al., 2012). IASI observations are then less suitable to efficiently monitor pollution in such cases.

\section{Conclusion}

Based on ozone and CO retrieval from IASI, we develop an analysis method to diagnose which processes contribute to ozone enhancement in the lower troposphere. We demonstrate that ozone profiles and semi-independent ozone columns between the surface and $12 \mathrm{~km}$ associated with simultaneous $\mathrm{CO}$ measurements from IASI provide a powerful observational data set to identify the stratospheric and anthropogenic origin of the lower-tropospheric ozone.

We show that UT ozone columns larger than $40 \mathrm{DU}$ are a proxy to identify the region of subsiding ozone associated with the tropopause perturbation induced by low-pressure weather systems. Combined with LT ozone columns larger than $\sim 30 \mathrm{DU}$, the UT ozone columns identify the areas in the lower troposphere affected by the UTLS reservoir of ozone. We show that the ozone subsiding transfer due to the tropopause perturbations associated with the low-pressure systems affect the free- and lower-tropospheric ozone over large regions. We determine the region of influence of such systems, located mainly above $40^{\circ} \mathrm{N}$, but with some particularly intense events (e.g. cut-off low from 11 to 13 May 2008) impacting southern regions such as the NCP for a few days. The vertical dimension provided by IASI allows the identification of the STE areas, which are located in the southern part behind the cold front in the case of the frontal system and on the southern or southeastern flanks of the low in the case of a cut-off low. Note that the STEs are expected to occur preferentially on the western and southern flanks of the trough.

Based on the case of a cut-off low travelling over the NCP from 11 to 14 May 2008, we show that such systems, with potential convective capacity,play a key role in the transboundary transport of pollutants when they travel over highly polluted regions. We identify from the $\mathrm{O}_{3} / \mathrm{CO}$ enhancement ratio estimated from IASI observations that significant ozone photochemical production occurs during the transport from the NCP on 12 May to the Sea of Japan on 14 May.

By contrast, we show that large LT ozone columns when not associated with large UT ozone columns but with enhanced CO total columns - used as a pollution tracer - indicate the areas where the photochemical production of ozone forms part of the observed ozone enhancement in the lower troposphere. Most of the enhanced lower-tropospheric ozone columns are observed in regions mainly impacted by strong pollution levels. Significant correlations between CO (used as a pollution tracer) and ozone in the lower troposphere as well as an enhancement ratio of $\mathrm{O}_{3}$ to $\mathrm{CO}$ have been found, consistent with those from literature. Moreover, the analysis of vertical sections of ozone concentrations over the NCP indicates that ozone concentrations are enhanced only in the lower troposphere in such regions, indicating the anthropogenic origin of the observed ozone enhancements. The maximal values of ozone are observed between 2 and $4 \mathrm{~km}$ in cases where an anticyclonic situation is well settled over the NCP (e.g. 5 and 15 May 2008). This is in agreement with in situ measurements (Huang et al., 2015), considering the limited vertical resolution of IASI and its limited sensitivity to surface ozone. Because of these limitations, it is not possible to determine more precisely the altitude of the ozone enhancements in the troposphere. This is all the more difficult when stratospheric and photochemical events occur at the same time. The lack of vertical resolution does not allow the various contributions to be differentiated. Combined with modelling studies, advanced satellite products coupling UV and IR information such as the recent IASI+GOME-2 product (Cuesta et al., 2013) as well as the next generation of satellite instruments (Crevoisier et al., 2014; Veefkind et al., 2012) should help address this issue.

\section{The Supplement related to this article is available online at doi:10.5194/acp-15-10839-2015-supplement.}

Acknowledgements. We acknowledge the Institut für Meteorologie und Klimaforschung (IMK), Karlsruhe, Germany, for a licence to use the KOPRA radiative transfer model. This study was supported by the French Space Agency - CNES (project "IASITOSCA"). The IASI mission is a joint mission of EUMETSAT and the Centre National d'Etudes Spatiales (CNES, France). The IASI L1 data are distributed in near real time by EUMETSAT through the EUMETCast system distribution. We acknowledge the Ether CNES/CNRS-INSU database (http://www.pole-ether.fr) for providing access to IASI Level 1 data. We acknowledge the LATMOS/ULB for the provision of IASI CO total columns through the Ether CNES/CNRS-INSU database. The authors gratefully acknowledge the NOAA Air Resources Laboratory (ARL) for the provision of the HYSPLIT transport and dispersion model 
and READY website (http://www.ready.noaa.gov) used in this publication. We acknowledge the free use of tropospheric $\mathrm{NO}_{2}$ column data from the GOME-2 sensor from www.temis.nl. The ozonesonde data used in this study were mainly provided by the World Ozone and Ultraviolet Data Centre (WOUDC), the Southern Hemisphere Additional Ozonesondes (SHADOZ), and the Global Monitoring Division (GMD) of NOAA's Earth System Research Laboratory and are publicly available (see http://www.woudc.org, http://croc.gsfc.nasa.gov/shadoz, http://www.esrl.noaa.gov/gmd). The authors thank all those responsible for the WOUDC, SHADOZ, and GMD measurements and archives for making the ozonesonde data available.

Edited by: P. Monks

\section{References}

Ancellet, G., Beekmann, M., and Papayannis, A.: Impact of a cutoff low development on downward transport of ozone in the troposphere, J. Geophys. Res., 99, 3451-3468, 1994.

Barret, B., Le Flochmoen, E., Sauvage, B., Pavelin, E., Matricardi, M., and Cammas, J. P.: The detection of post-monsoon tropospheric ozone variability over south Asia using IASI data, Atmos. Chem. Phys., 11, 9533-9548, doi:10.5194/acp-11-95332011, 2011.

Bethan, S., Vaughan, G., and Reid, S. J.: A comparison of ozone and thermal tropopause heights and the impact of tropopause definition on quantifying the ozone content of the troposphere, Q. J. Roy. Meteor. Soc., 122, 929-944, doi:10.1002/qj.49712253207, 1996.

Bethan, S., Vaughan, G., Gerbig, C., Volz-Thomas, A., Richer, H., and Tiddeman, D. A.: Chemical air mass differences near fronts, J. Geophys. Res., 103, 13413-13434, 1998.

Bey, I., Jacob, D. J., Logan, J. A., and Yantosca, R. M.: Asian chemical outflow to the Pacific in spring: Origins, pathways, and budgets, J. Geophys. Res., 106, 23097-23113, 2001.

Boersma, K. F., Eskes, H. J., and Brinksma, E. J.: Error Analysis for Tropospheric NO2 Retrieval from Space, J. Geophys. Res., 109, D04311, doi:10.1029/2003JD003962, 2004.

Bolton, D.: The computation of equivalent potential temperature, Mon. Weather Rev., 108, 1046-1053, 1980.

Boynard, A., Clerbaux, C., Coheur, P.-F., Hurtmans, D., Turquety, S., George, M., Hadji-Lazaro, J., Keim, C., and MeyerArnek, J.: Measurements of total and tropospheric ozone from IASI: comparison with correlative satellite, ground-based and ozonesonde observations, Atmos. Chem. Phys., 9, 6255-6271, doi:10.5194/acp-9-6255-2009, 2009.

Carmichael, G. R., Uno, I., Phadnis, M. J., Zhang, Y., and Sunwoo, Y.: Tropospheric ozone production and transport in the springtime in east Asia, J. Geophys. Res., 103, 10649-10671, 1998.

Chan, C. K. and Yao, X., Air pollution in mega cities in China, Atmos. Environ., 42, 1-42, 2008.

Clarisse, L., R'Honi, Y., Coheur, P.-F., Hurtmans, D., and Clerbaux, C.: Thermal infrared nadir observations of 24 atmospheric gases, Geophys. Res. Lett., 38, L10802, doi:10.1029/2011GL047271, 2011.

Clerbaux, C., Boynard, A., Clarisse, L., George, M., Hadji-Lazaro, J., Herbin, H., Hurtmans, D., Pommier, M., Razavi, A., Turquety,
S., Wespes, C., and Coheur, P.-F.: Monitoring of atmospheric composition using the thermal infrared IASI/MetOp sounder, Atmos. Chem. Phys., 9, 6041-6054, doi:10.5194/acp-9-6041-2009, 2009.

Coheur, P.-F., Barret, B., Turquety, S., Hurtmans, D., Hadji-Lazaro, J., and Clerbaux, C.: Retrieval and characterization of ozone vertical profiles from a thermal infrared nadir sounder, J. Geophys. Res., 110, D24303, doi:10.1029/2005JD005845, 2005.

Cooper, O. R., Moody, J. L., Davenport, J. C., Oltmans, S. J., Johnson, B. J., Chen, X., Shepson, P. B., and Merrill, J. T.: Influence of springtime weather systems on vertical ozone distribution over three North American sites, J. Geophys. Res., 103, 2200122013, 1998.

Cooper, O. R., Moody, J. L., Parrish, D. D., Trainer, M., Holloway, J. S., Hübler, G., Fehsenfeld, F. C., and, Stohl, A.: Trace gas composition of midlatitude cyclones over the western North Atlantic Ocean: A seasonal comparison of $\mathrm{O}_{3}$ and CO, J. Geophys. Res., 107, 4057, doi:10.1029/2001JD000902, 2002a.

Cooper, O. R., Moody, J. L., Parrish, D. D., Trainer, M., Ryerson, T. B., Holloway, J. S., Hübler, G., Fehsenfeld, F. C., and Evans, M. J.: Trace gas composition of midlatitude cyclones over the western North Atlantic Ocean: A conceptual model, J. Geophys. Res., 107, 4056, doi:10.1029/2001JD000901, 2002b.

Cooper, O. R., Forster C., Parrish, D., Trainer, M., Dunlea, E., Ryerson, T., Hübbler, G., Fehsenfeld, F., Nicks, D., Holloway, J., de Gouw, J., Warneke, C., Roberts, J. M., Flocke, F., and Moody, J.: A case study of transpacific warm conveyor belt transport: Influence of merging airstreams on trace gas import to North America, J. Geophys. Res., 109, D23S08, doi:10.1029/2003JD003624, 2004.

Crevoisier, C., Clerbaux, C., Guidard, V., Phulpin, T., Armante, R., Barret, B., Camy-Peyret, C., Chaboureau, J.-P., Coheur, P.F., Crépeau, L., Dufour, G., Labonnote, L., Lavanant, L., HadjiLazaro, J., Herbin, H., Jacquinet-Husson, N., Payan, S., Péquignot, E., Pierangelo, C., Sellitto, P., and Stubenrauch, C.: Towards IASI-New Generation (IASI-NG): impact of improved spectral resolution and radiometric noise on the retrieval of thermodynamic, chemistry and climate variables, Atmos. Meas. Tech., 7, 4367-4385, doi:10.5194/amt-7-4367-2014, 2014.

Cuesta, J., Eremenko, M., Liu, X., Dufour, G., Cai, Z., Höpfner, M., von Clarmann, T., Sellitto, P., Foret, G., Gaubert, B., Beekmann, M., Orphal, J., Chance, K., Spurr, R., and Flaud, J.-M.: Satellite observation of lowermost tropospheric ozone by multispectral synergism of IASI thermal infrared and GOME-2 ultraviolet measurements over Europe, Atmos. Chem. Phys., 13, 9675-9693, doi:10.5194/acp-13-9675-2013, 2013.

Draxler, R. R. and Rolph, G. D: HYSPLIT (HYbrid SingleParticle Lagrangian Integrated Trajectory), available at: http: //www.arl.noaa.gov/HYSPLIT.php (last access: 24 September 2015), NOAA Air Resources Laboratory, Silver Spring, MD, 2015.

Dee, D. P., Uppala, S. M., Simmons, A. J., Berrisford, P., Poli, P., Kobayashi, S., Andrae, U., Balmaseda, M. A., Balsamo, G., Bauer, P., Bechtold, P., Beljaars, A. C. M., van de Berg, L., Bidlot, J., Bormann, N., Delsol, C., Dragani, R., Fuentes, M., Geer, A. J., Haimberger, L., Healy, S. B., Hersbach, H., Hólm, E. V., Isaksen, L., Kållberg, P., Köhler, M., Matricardi, M., McNally, A. P., Monge-Sanz, B. M., Morcrette, J.-J., Park, B.-K., Peubey, C., de Rosnay, P., Tavolato, C., Thépaut, J.-N., and Vitart, F.: The 
ERA-Interim reanalysis: configuration and performance of the data assimilation system, Q. J. Roy. Meteor. Soc., 137, 553-597, doi:10.1002/qj.828, 2011.

de Laat, A. T. J., Aben, I., and Roelofs, G. J.: A model perspective on total tropospheric $\mathrm{O}_{3}$ column variability and implications for satellite observations, J. Geophys. Res., 110, D13303, doi:10.1029/2004JD005264, 2005.

Dempsey, F.: Observations of stratospheric $\mathrm{O}_{3}$ intrusions in air quality monitoring data in Ontario, Canada, Atmos. Environ., 98, 111-122, doi:10.1016/j.atmosenv.2014.08.024, 2014.

Ding, A., Wang, T., Xue, L., Gao, J., Stohl, A., Lei, H., Jin, D., Ren, Y., Wang, X., Wei, X., Qi, Y., Liu, J., and Zhang, X.: Transport of north China air pollution by midlatitude cyclones: Case study of aircraft measurements in summer 2007, J. Geophys. Res., 114, D08304, doi:10.1029/2008JD011023, 2009.

Ding, A. J., Wang, T., Thouret, V., Cammas, J.-P., and Nédélec, P.: Tropospheric ozone climatology over Beijing: analysis of aircraft data from the MOZAIC program, Atmos. Chem. Phys., 8, 1-13, doi:10.5194/acp-8-1-2008, 2008.

Ding, K., Liu, J., Ding, A., Liu, Q., Zhao, T. L., Shi, J., Han, Y., Wang, H., and Jiang, F.: Uplifting of carbon monoxide from biomass burning and anthropogenic sources to the free troposphere in East Asia, Atmos. Chem. Phys., 15, 2843-2866, doi:10.5194/acp-15-2843-2015, 2015.

Doche, C., Dufour, G., Foret, G., Eremenko, M., Cuesta, J., Beekmann, M., and Kalabokas, P.: Summertime tropospheric-ozone variability over the Mediterranean basin observed with IASI, Atmos. Chem. Phys., 14, 10589-10600, doi:10.5194/acp-1410589-2014, 2014.

Dufour, G., Eremenko, M., Orphal, J., and Flaud, J.-M.: IASI observations of seasonal and day-to-day variations of tropospheric ozone over three highly populated areas of China: Beijing, Shanghai, and Hong Kong, Atmos. Chem. Phys., 10, 37873801, doi:10.5194/acp-10-3787-2010, 2010.

Dufour, G., Eremenko, M., Griesfeller, A., Barret, B., LeFlochmoën, E., Clerbaux, C., Hadji-Lazaro, J., Coheur, P.-F., and Hurtmans, D.: Validation of three different scientific ozone products retrieved from IASI spectra using ozonesondes, Atmos. Meas. Tech., 5, 611-630, doi:10.5194/amt-5-611-2012, 2012.

Edwards, D. P., Emmons, L. K., Hauglustaine, D. A., Chu, A., Gille, J. C., Kaufman, Y. J., P'etron, G., Yurganov, L. N., Giglio, L., Deeter, M. N., Yudin, V., Ziskin, D. C., Warner, J., Lamarque, J.F., Francis, G. L., Ho, S. P., Mao, D., Chan, J., and Drummond, J. R.: Observations of Carbon Monoxide and Aerosol From the Terra Satellite: Northern Hemisphere Variability, J. Geophys. Res.-Atmos., 109, D24202, doi:10.1029/2004JD004727, 2004.

Eremenko, M., Dufour, G., Foret, G., Keim, C., Orphal, J., Beekmann, M., Bergametti, G., and Flaud, J.-M.: Tropospheric ozone distributions over Europe during the heat wave in July 2007 observed from infrared nadir spectra recorded by IASI, Geophys. Res. Lett., 35, L18805, doi:10.1029/2008GL034803, 2008.

Fishman, J., Wozniak, A. E., and Creilson, J. K.: Global distribution of tropospheric ozone from satellite measurements using the empirically corrected tropospheric ozone residual technique: Identification of the regional aspects of air pollution, Atmos. Chem. Phys., 3, 893-907, doi:10.5194/acp-3-893-2003, 2003.

Foret, G., Eremenko, M., Cuesta, J., Sellitto, P., Barré, J., Gaubert, B., Coman, A., Dufour, G., Liu, X., Joly, M., Doche, C., and Beekmann, M.: Ozone pollution: what can we see from space? A case study, J. Geophys. Res.-Atmos., 119, 8476-8499, doi:10.1002/2013JD021340, 2014.

George, M., Clerbaux, C., Hurtmans, D., Turquety, S., Coheur, P.F., Pommier, M., Hadji-Lazaro, J., Edwards, D. P., Worden, H., Luo, M., Rinsland, C., and McMillan, W.: Carbon monoxide distributions from the IASI/METOP mission: evaluation with other space-borne remote sensors, Atmos. Chem. Phys., 9, 8317-8330, doi:10.5194/acp-9-8317-2009, 2009.

Hannan, J. R., Fuelberg, H. E., Crawford, J. H., Sachse, G. W., and Blake D. R.:Role of wave cyclones in transporting boundary layer air to the free troposphere during the spring 2001 NASA/TRACE-P experiment, J. Geophys. Res., 108, 8782, doi:10.1029/2002JD003105, 2003.

Hayashida, S., Liu, X., Ono, A., Yang, K., and Chance, K.: Observation of ozone enhancement in the lower troposphere over East Asia from a space-borne ultraviolet spectrometer, Atmos. Chem. Phys., 15, 9865-9881, doi:10.5194/acp-15-9865-2015, 2015.

Holton, J. R.: An introduction to dynamic meteorology, 4th Edn., Elsevier, New York, 2004.

Holton, J. R., Haynes, P. H., McIntyre, M. E., Douglass, A. R., Rood, R. B., and Pfister, L.: Stratosphere-troposphere exchange, Rev. Geophys., 33, 403-439, 1995.

Höpfner, M., Blom, C. E., Echle, G., Glatthor, N., Hase, F., and Stiller, G.: Retrieval simulations for MIPAS-STR measurements, edited by: Smith, W. L., IRS 2000: Current Problems in Atmospheric Radiation, Proc. of the Internat. Radiation Symp., St. Petersburg, Russia, 24-29 July 2000, DEEPAK Publ., Hampton, Va., 2001.

Huang, J., Liu, H., Crawford, J. H., Chan, C., Considine, D. B., Zhang, Y., Zheng, X., Zhao, C., Thouret, V., Oltmans, S. J., Liu, S. C., Jones, D. B. A., Steenrod, S. D., and Damon, M. R.: Origin of springtime ozone enhancements in the lower troposphere over Beijing: in situ measurements and model analysis, Atmos. Chem. Phys., 15, 5161-5179, doi:10.5194/acp-15-5161-2015, 2015.

Hurtmans, D., Coheur, P.-F., Wespes, C., Clarisse, L., Scharf, O., Clerbaux, C., Hadji-Lazaro, J., George, M., and Turquety, S.: FORLI radiative transfer and retrieval code for IASI, J. Quant. Spectrosc. Ra., 113, 1391-1408, doi:10.1016/j.jqsrt.2012.02.036, 2012.

Jaffe, D., Anderson, T., Covert, D., Kotchenruther, R., Trost, B., Danielson, J., Simpson, W., Berntsen T., Karlsdottir, S., Blake, D., Harris, J., Carmichael, G., and Uno, I.: Transport of Asian air pollution to North America, Geophys. Res. Lett., 26, 711-714, 1999.

Kulawik, S. S., Osterman, G., Jones, D. B. A., and Bowman, K.W.: Calculation of altitude-dependent Tikhonov constraints for TES nadir retrievals, IEEE T. Geosci. Remote, 44, 1334-1342, 2006.

Lelieveld, J. and Dentener, F. J.: What controls tropospheric ozone?, J. Geophys. Res., 105, 3531-3551, 2000.

Li, J., Wang, Z., Akimoto, H., Gao, C., Pochanart, P., and Wang, X.: Modeling study of ozone seasonal cycle in lower troposphere over east Asia, J. Geophys. Res., 112, D22S25, doi:10.1029/2006JD008209, 2007.

Liang, Q., Jaeglé, L., Jaffe, D. A., Weiss-Penzias, P., Heckman, A., and Snow, J. A.: Long-range transport of Asian pollution to the northeast Pacific: Seasonal variations and transport pathways of carbon monoxide, J. Geophys. Res., 109, D23S07, doi:10.1029/2003JD004402, 2004. 
Lin, J., Pan, D., and Zhang, R.-X.: Trend and Interannual Variability of Chinese Air Pollution since 2000 in Association with Socioeconomic Development: A Brief Overview, Atmos. Oceanic Sci. Lett., 6, 84-89, 2013.

Lin, M., Holloway, T., Carmichael, G. R., and Fiore, A. M.: Quantifying pollution inflow and outflow over East Asia in spring with regional and global models, Atmos. Chem. Phys., 10, 42214239, doi:10.5194/acp-10-4221-2010, 2010.

Liu, C. X., Liu, Y., Liu, X., and Chance, K.: Dynamical and chemical features of a cutoff low over Noertheast China in July 2007: Results from satellite measurements and reanalysis, Adv. Atmos. Sci., 30, 525-540, doi:10.1007/s00376-012-2086-8, 2013.

Liu, H., Jacob, D. J., Bey, I., Yantosca, R. M., Duncan, B. N., and Sachse, G. W.: Transport pathways for Asian pollution outflow over the Pacific: Interannual and seasonal variations, J. Geophys. Res., 108, 8786, doi:10.1029/2002JD003102, 2003.

Liu, X., Chance, K., and Kurosu, T. P.: Improved ozone profile retrievals from GOME data with degradation correction in reflectance, Atmos. Chem. Phys., 7, 1575-1583, doi:10.5194/acp7-1575-2007, 2007.

Liu, X., Bhartia, P. K., Chance, K., Spurr, R. J. D., and Kurosu, T. P.: Ozone profile retrievals from the Ozone Monitoring Instrument, Atmos. Chem. Phys., 10, 2521-2537, doi:10.5194/acp-10-25212010, 2010.

Mari, C., Evans, M. J., Palmer, P. I., Jacob, D. J., and Sachse, G. W.: Export of Asian pollution during two cold front episodes of the TRACE-P experiment, J. Geophys. Res., 109, D15S17, doi:10.1029/2003JD004307, 2004.

Mauzerall, D. L., Narita, D., Akimoto, H., Horowitz, L., Walters, S., Hauglustaine, D. A., and Brasseur, G.: Seasonal characteristics of tropospheric ozone production and mixing ratios over East Asia: A global three-dimensional chemical transport model analysis, J. Geophys. Res., 105, 17895-17910, doi:10.1029/2000JD900087, 2000

McMillan, W. W., Pierce, R., Sparling, L. C., Osterman, G., McCann, K., Fischer, M. L., Rappenglueck, B., Newton, R., Turner, D. D., Kittaka, C., Evans, K., Biraud, S., Lefer, B., Andrews, A., and Oltmans, S.: An Observational and modeling strategy to investigate the impact of remote sources on local air quality: A Houston, Texas case study from TEXAQS II, J. Geophys. Res.Atmos., 115, D01301, doi:10.1029/2009JD011973, 2010.

McPeters, R. D., Labow, G. J., and Logan, J. A.: Ozone climatological profiles for satellite retrieval algorithms, J. Geophys. Res., 112, D05308, doi:10.1029/2005JD006823, 2007.

Miyazaki, Y., Kondo, Y., Koike, M., Fuelberg, H. E., Kiley, C. M., Kita, K., Takegawa, N., Sachse, G. W., Flocke, F., Weinheimer, A. J., Singh, H. B., Eisele, F. L., Zondlo, M., Talbot, R. W., Sandholm, S. T., Avery, M. A., and Blake, D. R.: Synoptic-scale transport of reactive nitrogen over the western Pacific in spring, J. Geophys. Res., 108, 8788, doi:10.1029/2002JD003248, 2003.

Monks, P. S.: A review of the observations and origins of the spring ozone maximum, Atmos. Environ., 34, 3545-3561, 2000.

Monks, P. S.: Gas-phase radical chemistry in the troposphere, Chem. Soc. Rev., 34, 376-395, 2005.

Monks, P. S., Archibald, A. T., Colette, A., Cooper, O., Coyle, M., Derwent, R., Fowler, D., Granier, C., Law, K. S., Mills, G. E., Stevenson, D. S., Tarasova, O., Thouret, V., von Schneidemesser, E., Sommariva, R., Wild, O., and Williams, M. L.: Tropospheric ozone and its precursors from the urban to the global scale from air quality to short-lived climate forcer, Atmos. Chem. Phys., 15 8889-8973, doi:10.5194/acp-15-8889-2015, 2015.

Nakatani, A., Kondo, S., Hayashida, S., Nagashima, T., Sudo, K., Liu, X., Chance, K., and Hirota, I.: Enhanced mid-latitude tropospheric column ozone over East Asia: Couple effects of stratospheric ozone intrusion and anthropogenic sources, J. Meteorol. Soc. Jpn., 90, 207-222, 2012.

Oshima, N., Koike, M., Nakamura, H., Kondo, Y., Takegawa, N., Miyazaki, Y., Blake, D. R., Shirai, T., Kita, K., Kawakami, S., and, Ogawa, T.: Asian chemical outflow to the Pacific in late spring observed during the PEACE-B aircraft mission, J. Geophys. Res., 109, D23S05, doi:10.1029/2004JD004976, 2004.

Richter, A., Burrows, J. P., Nub, H., Granier, C., and Niemeier, U.: Increase in tropospheric nitrogen dioxide over China observed from space, Nature, 437, 129-132, 2005.

Rodgers, C. D.: Inverse methods for atmospheric sounding: Theory and practice, vol. 2, World Scientific Publications, Series on Atmospheric, Ocean, Planet. Phys., Singapore, 2000.

Rolph, G. D. Real-time Environmental Applications and Display sYstem, available at: http://www.ready.noaa.gov (last access: 24 September 2015), NOAA Air Resources Laboratory, Silver Spring, MD, 2015.

Safieddine, S., Clerbaux, C., George, M., Hadji-Lazaro, J., Hurtmans, D., Coheur, P.-F., Wespes, C., Loyola, D., Valks, P., and Hao, N.: Tropospheric ozone and nitrogen dioxide measurements in urban and rural regions as seen by IASI and GOME-2, J. Geophys. Res.-Atmos., 118, 10555-10566, doi:10.1002/jgrd.50669, 2013.

Schuepbach, E., Davies, T. D., and Massacand, A. C.: An usual springtime ozone episode at high elevation in the Swiss Alps: contributions both from cross-tropopause exchange and from the boundary layer, Atmos. Environ., 33, 1735-1744, 1999.

Seinfeld, J. H. and Pandis, S. N.: Atmospheric Chemistry and Physics, from Air Pollution to Climate Change, John Wiley \& Sons Inc., Toronto, Canada, 1997.

Stevenson, D. S., Dentener, F. J., Schultz, M. G., Ellingsen, K., van Noije, T. P. C., Wild, O., Zeng, G., Amann, M., Atherton, C. S., Bell, N., Bergmann, D. J., Bey, I., Butler, T., Cofala, J., Collins, W. J., Derwent, R. G., Doherty, R. M., Drevet, J., Eskes, H. J., Fiore, A. M., Gauss, M., Hauglustaine, D. A., Horowitz, L.W., Isaksen, I. S. A., Krol, M. C., Lamarque, J. F., Lawrence, M. G., Montanaro, V., Muller, J. F., Pitari, G., Prather, M. J., Pyle, J. A., Rast, S., Rodriguez, J. M., Sanderson, M. G., Savage, N. H., Shindell, D. T., Strahan, S. E., Sudo, K., and Szopa, S.: Multimodel ensemble simulations of present-day and near-future tropospheric ozone, J. Geophys. Res.-Atmos., 111, D08301, doi:10.1029/2005jd006338, 2006.

Stiller, G. P. (Ed.), Clarmann, T., Dudhia, A., Echle, G., Funke, B., Glatthor, N., Hase, F., Höpfner, M., Kellmann, S., Kemnitzer, H., Kuntz, M., Linden, A., Linder, M., Stiller, G. P., and Zorn, S.: The Karlsruhe Optimized and Precise Radiative Transfer Algorithm (KOPRA), vol. FZKA 6487 of Wissenschaftliche Berichte, Forschungszentrum Karlsruhe, Germany, 2000.

Tanimoto, H., Sawa, Y., Matsueda, H., Uno, I., Ohara, T., Yamaji, K., Kurokawa, J., and Yonemura, S.: Significant latitudinal gradient in the surface ozone spring maximum over East Asia, Geophys. Res. Lett., 32, L21805, doi:10.1029/2005GL023514, 2005.

Tanimoto, H., Sawa, Y., Yonemura, S., Yumimoto, K., Matsueda, H., Uno, I., Hayasaka, T., Mukai, H., Tohjima, Y., Tsuboi, K., and 
Zhang, L.: Diagnosing recent CO emissions and ozone evolution in East Asia using coordinated surface observations, adjoint inverse modeling, and MOPITT satellite data, Atmos. Chem. Phys., 8, 3867-3880, doi:10.5194/acp-8-3867-2008, 2008.

Tikhonov, A.: On the Solution of Incorrectly Stated Problems and a Method of Regularisation, Dokl. Acad. Nauk SSSR, 151, 501504, 1963.

Veefkind, J. P., Aben, I., McMullan, K., Förster, H., de Vries, J., Otter, G., Claas, J., Eskes, H. J., de Haan, J. F., Kleipool, Q., van Weele, M., Hasekamp, O., Hoogeveen, R., Landgraf, J., Snel, R., Tol, P., Ingmann, P., Voors, R., Kruisinga, B., Vink, R., Visser, H., and Levelt, P. F.: TROPOMI on the ESA Sentinel-5 Precursor: A GMES mission for global observations of the atmospheric composition for climate, air quality and ozone layer applications, Remote Sens. Environ., 120, 70-83, doi:10.1016/j.rse.2011.09.027, 2012.

Wang, Y., Konopka, P., Liu, Y., Chen, H., Müller, R., Plöger, F., Riese, M., Cai, Z., and Lü, D.: Tropospheric ozone trend over Beijing from 2002-2010: ozonesonde measurements and modeling analysis, Atmos. Chem. Phys., 12, 8389-8399, doi:10.5194/acp-12-8389-2012, 2012.

Worden, H. M., Logan, J. A., Worden, J. R., Beer, R., Bowman, K., Clough, S. A., Eldering, A., Fisher, B. M., Gunson, M. R., Herman, R. L., Kulawik, S. S., Lampel, M. C., Luo, M., Megretskaia, I. A., Osterman, G. B., and Shephard, M. W.: Comparisons of Tropospheric Emission Spectrometer (TES) ozone profiles to ozonesondes: Methods and initial results, J. Geophys. Res., 112, D03309, doi:10.1029/2006JD007258, 2007.
World Health Organization (WHO): Review of evidence on health aspects of air pollution - REVIHAAP project: final technical report, WHO/Europe, 2013.

World Meteorological Organization (WMO): International list of selected and supplementary ships, 3, WMO 47 (WMO/OMM 47, TP. 18), 143 pp., 1957.

Yamaji, K., Ohara, T., Uno, I., Tanimoto, H., Kurokawa, J., and Akimoto, H.: Analysis of the seasonal variation of ozone in the boundary layer in East Asia using the Community Multiscale Air Quality model: What controls surface ozone levels over Japan?, Atmos. Environ., 40, 1856-1868, 2006.

Zhao, C., Wang, Y., and Zeng, T.: East China plains: a "basin" of ozone pollution, Environ. Sci. Technol., 43, 1911-1915, 2009.

Zhou, D. K., Larar, A. M., Liu, X., Smith, W. L., Strow, L. L., Yang, P., Schlussel, P., and Calbet, X.: Global land surface emissivity retrieved from satellite ultraspectral IR measurements, IEEE T. Geosci. Remote, 49, 1277-1290, 2011. 